\title{
Toll-Like Receptors: Role in Dermatological Disease
}

\author{
Aswin Hari, ${ }^{1,2}$ Tracy L. Flach, , 2 Yan Shi, ${ }^{1,2}$ and P. Régine Mydlarski, 3 \\ ${ }^{1}$ Immunology Research Group, University of Calgary, Calgary, AB, Canada T2N 4N1 \\ ${ }^{2}$ Department of Microbiology \& Infectious Diseases, University of Calgary, Calgary, AB, Canada T2N 4N1 \\ ${ }^{3}$ Department of Medicine, University of Calgary, Calgary, AB, Canada T2N 4N1 \\ Correspondence should be addressed to Aswin Hari, haria@ucalgary.ca
}

Received 29 January 2010; Revised 27 April 2010; Accepted 1 July 2010

Academic Editor: Natalija Novak

Copyright (C) 2010 Aswin Hari et al. This is an open access article distributed under the Creative Commons Attribution License, which permits unrestricted use, distribution, and reproduction in any medium, provided the original work is properly cited.

Toll-like receptors (TLRs) are a class of conserved receptors that recognize pathogen-associated molecular patterns (PAMPs) present in microbes. In humans, at least ten TLRs have been identified, and their recognition targets range from bacterial endotoxins to lipopeptides, DNA, dsRNA, ssRNA, fungal products, and several host factors. Of dermatological interest, these receptors are expressed on several skin cells including keratinocytes, melanocytes, and Langerhans cells. TLRs are essential in identifying microbial products and are known to link the innate and adaptive immune systems. Over the years, there have been significant advances in our understanding of TLRs in skin inflammation, cutaneous malignancies, and defence mechanisms. In this paper, we will describe the association between TLRs and various skin pathologies and discuss proposed TLR therapeutics.

\section{Introduction}

Toll receptors were first discovered in Drosophila where they are involved in embryogenesis [1]. They were later shown to assist in innate immunity where their activation resulted in the production of antimicrobial peptides. Thus, structurally similar receptors found in other species were named tolllike receptors (TLRs) $[1,2]$. In mammals, TLRs represent a family of pattern recognition receptors (PRRs) that recognize distinct, conserved microbial components and permit cells to recognize self from nonself in immune activation [1, 3]. The TLR family represents a known group of at least 10 human transmembrane proteins which are essential for innate immunity [4]. Immune cells such as monocytes, macrophages, dendritic cells, granulocytes, and nonimmune cells like keratinocytes express TLRs. Predictably, TLRs are mostly found on cells that initiate the primary immune response. TLRs detect a variety of PAMPs which include Lipopolysaccharide (TLR 4), double-stranded (DS) RNA (TLR 3), and single-stranded (SS) RNA (TLR 7) [5, 6]. These receptors are located on the cell surface, the endocytic vesicle membrane, or intracellular organelles [6]. TLRs have an ectodomain composed of leucine-rich repeats (LRRs) that may bind directly to ligands [2]. Alternately, accessory molecules may also be involved in ligand binding in addition to a cytoplasmic toll/interleukin-1 (IL-1) receptor (TIR) domain, which interacts with TIR-domain-containing adaptor molecules [6]. In the case of human TLR 4, two accessory molecules CD14 and MD2 are essential for LPS recognition $[2,7,8]$. TLRs have the ability to initiate a rapid and potent response upon ligand engagement. While TLRs are single-membrane spanning noncatalytic receptors; different TLRs are able to pair up with each other to expand their range of recognition targets. For instance, TLR 1 and 2 pair up and sense peptidoglycans. While most TLRs signal through the Myd88 pathway (Myeloid differentiation factor88 ), TLR 3 and 4 utilize the TRIF pathway (TIR domaincontaining adapter protein that induces IFN- $\beta$ ), and TRAF 6 (TNF receptor-associated factor 6) was found to be the additional transducer for TLR 7 and $9[9,10]$. Ensuing these signalling intermediates, TLRs eventually trigger nuclear factor kappa-light-chain-enhancer of activated B cells- $(\mathrm{NF}-\kappa \mathrm{B})$ dependent and interferon regulatory factor (IRF-) dependent activation events [9]. Activation of these transcription factors results in induction of immune and inflammatory genes, namely, tumor necrosis factor alpha (TNF- $\alpha$ ) and type I interferons (IFNs) [9]. At these events, TLR-mediated activation is quite similar to that of another important inflammatory cytokine receptor, interleukin-1 receptor (IL1R). TLRs and IL-1R share the Myd88 adaptor molecule 
and promote the production of proinflammatory cytokines such as leukotrienes (LTs), prostaglandins, and chemokines [4]. Once activated by TLRs, immune cells initiate phagocytosis/killing of pathogens, cytokine, and chemokine production, leukocyte activation, and antigen presentation to $\mathrm{T}$ cells, thereby, initiating an adaptive immune response. An in-depth insight into different TLRs and their associated characteristics such as ligands, cytokines induction profile and functions have been previously explained by others [11]. TLRs can modulate adaptive response with respect to Th1 and Th2 as reported in study, by Medzhitov et al. $[2,12]$. The study found that the mice lacking Myd88 were defective in giving rise to antigen-specific Th1 $\mathrm{T}$ helper cells but could initiate a normal Th2 response. All TLR ligands trigger Th1 response which seem essential in defence against microbial antigens that are viral, bacterial, and fungal in nature, in contrast to specific interaction against antigens such as helminths that require a Th2 response [2].

The skin is the first line of defence against a variety of physical and biological assaults. It shields the body from harmful chemicals, physical trauma, and ultraviolet (UV) radiation. In addition, it is essential in maintaining temperature and homeostasis and in our sensing of the environment. The skin has evolved into a complicated, yet tightly regulated system appropriate for the complex functionalities associated within it. The outermost layer of the skin is the epidermis and is composed of four main types of cells: keratinocytes, Langerhans cells, melanocytes, and Merkel cells (Figure 1(a)). Keratinocytes are capable of proliferating and maintaining the outer layer which is composed of a stratified epithelial zone and a water resistant layer of lipids on the outmost surface. The melanocytes residing in the skin provide the melanin pigment that is essential for protection against UV radiation. Interspersed between keratinocytes and melanocytes are the Langerhans cells (which function as cutaneous antigen presenting cells (APCs)) and intraepithelial T lymphocytes. Merkel cells are oval sensory cells found in the skin. They play a role in light touch discrimination and may have a neuroendocrine function. The epidermis is anchored to the dermis below via connective tissues. The dermis is rich in blood vessels, nerves and has abundant fibroblasts, dendritic cells, macrophages, and lymphocytes.

The repertoire of TLRs found on each of these three epidermal cell types varies (Figure 1(a)). Even though the precise role against pathogens is poorly understood, in general, TLRs in the skin respond to their ligands by activating NF- $\kappa \mathrm{B}$ and producing cytokines [13]. Keratinocytes are reported to express TLRs $1,2,3,5$, 9, and 10 [14-21]; the evidence supporting TLR 4 expression in keratinocytes is conflicting [14, 18-20] (Figure 1(b)). As an example of TLR 2 engagement, human keratinocytes mainly signal through TLR 2 once activated with Staphylococcus aureus (S. aureus) or Candida albicans $[15,20]$. Keratinocytes, treated with $S$. aureus, transcribe NF- $\kappa \mathrm{B}$ controlled genes (cyclooxygenase2 , nitric oxide synthetase, and IL-8) and produce enhanced levels of IL-8, nitric oxide, and chemokines [15]. Ligands for TLR 2, 3, and 5 stimulate production of matrix metalloproteases (MMPs) 1 and 9, along with activation of the NF- $\kappa$ B pathway [22]. The expression of these cytokines is needed for proper recruitment, inflammation, and damaged tissue remodelling [22]. Translocation of NF- $\kappa \mathrm{B}$ and the associated events permits keratinocytes to stimulate dendritic cell maturation and enhance antigen presentation [23]. Activated keratinocytes are also important epidermal cytokine producers which mobilize leukocytes, signal other cutaneous cells and attract neutrophil granulocytes and professional killer cells [20]. Langerhans cells express significant levels of TLRs 2, 3, 4, 8, and 10 and low levels of TLRs 1 , 5, 6, 7, and 9 [24] (Figure 1(c)). DS RNA, present in some viruses, induces a particularly robust response in Langerhans cells, implicating its role in anti-viral immunity via TLR 3 [25]. Additionally, Langerhans cells can be activated indirectly by activated myeloid derived dendritic cells and keratinocytes (Figure 1(d)). For example, they were found to mature and initiate a Th1 response in the presence of keratinocytes that secreted IFN $\alpha$ and IL-18 upon exposure to antigen, such as DS RNA or polyinosinic-polycytidylic acid (poly IC) stimulation [23]. Lastly, human melanocytes have been shown to express TLRs 2, 3, 4, 7, 9 (at the protein level), and respond to TLR 4 ligands by MMP induction $[25,26]$ (Figure 1(e)). When stimulated by TLR ligands, human melanocytes can: (1) release IL-6 and IL-8 cytokines, (2) enhance chemokine (CCL2, CCL3, and CCL5) mRNA production, (3) upregulate phosphorylated $\mathrm{I} \kappa \mathrm{B} \alpha$ (nuclear factor of kappa light polypeptide gene enhancer in B-cells inhibitor, alpha), and (4) promote translocation of NF$\kappa \mathrm{Bp} 65$ to the nucleus [25].

TLRs are increasingly being implicated in many immune and inflammatory diseases, cancer, and wound healing. For example, TLR 2, TLR 4, TLR 5, and TLR 7 are implicated in tumor metastasis, sepsis, radioprotection, and systemic lupus erythematosus, respectively [83]. Wound healing

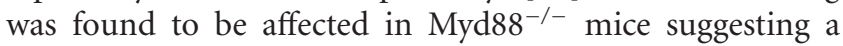
synergistic role for TLRs in this process [84]. That study revealed interplay between purinogenic receptor signalling and Myd $88^{-/-}$pathways but did not explore IL-1 cytokine profile. The involvement of Myd88 hints at an important function of associated TLRs, especially TLR 2 and 4, in slain tissue remodelling. Lai et al. revealed a novel mechanism by which bacterial products modulate local inflammation in a TLR 2-dependent manner [85]. Understanding TLR signalling pathways, their structural interaction with ligands, and inhibition strategies may provide avenues for potential clinical intervention [83]. In order to clinically manipulate TLRs, pharmacologics should alter TLR activity through receptor antagonists, receptor agonists and signal transduction inhibitors. Moreover, neutralizing antibodies, monotherapies and adjuvancy may also be used to target TLRs. E5564 (Eritoran) is a good example of a current pharmacological (TLR 4 antagonist) agent which is being clinically tested for treatment of Gram-negative endotoxemia and sepsis [83]. TLR-mediated activation or dysfunction has been attributed to exacerbation of different diseases. The manipulation of specific TLRs may therefore lead to the development of novel therapies for autoimmunity, cancer, and inflammatory disease. Next we will discuss how 

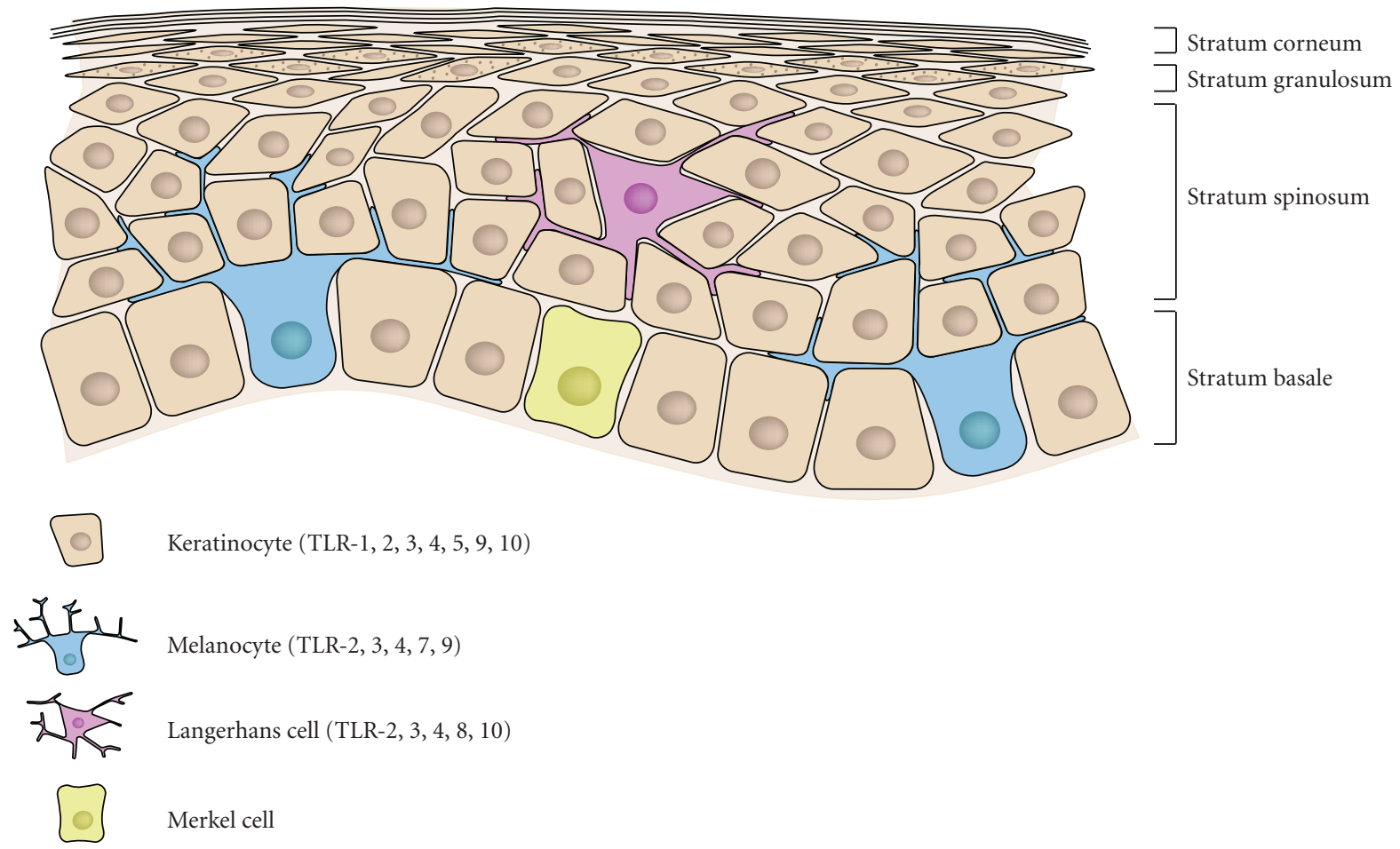

(a)

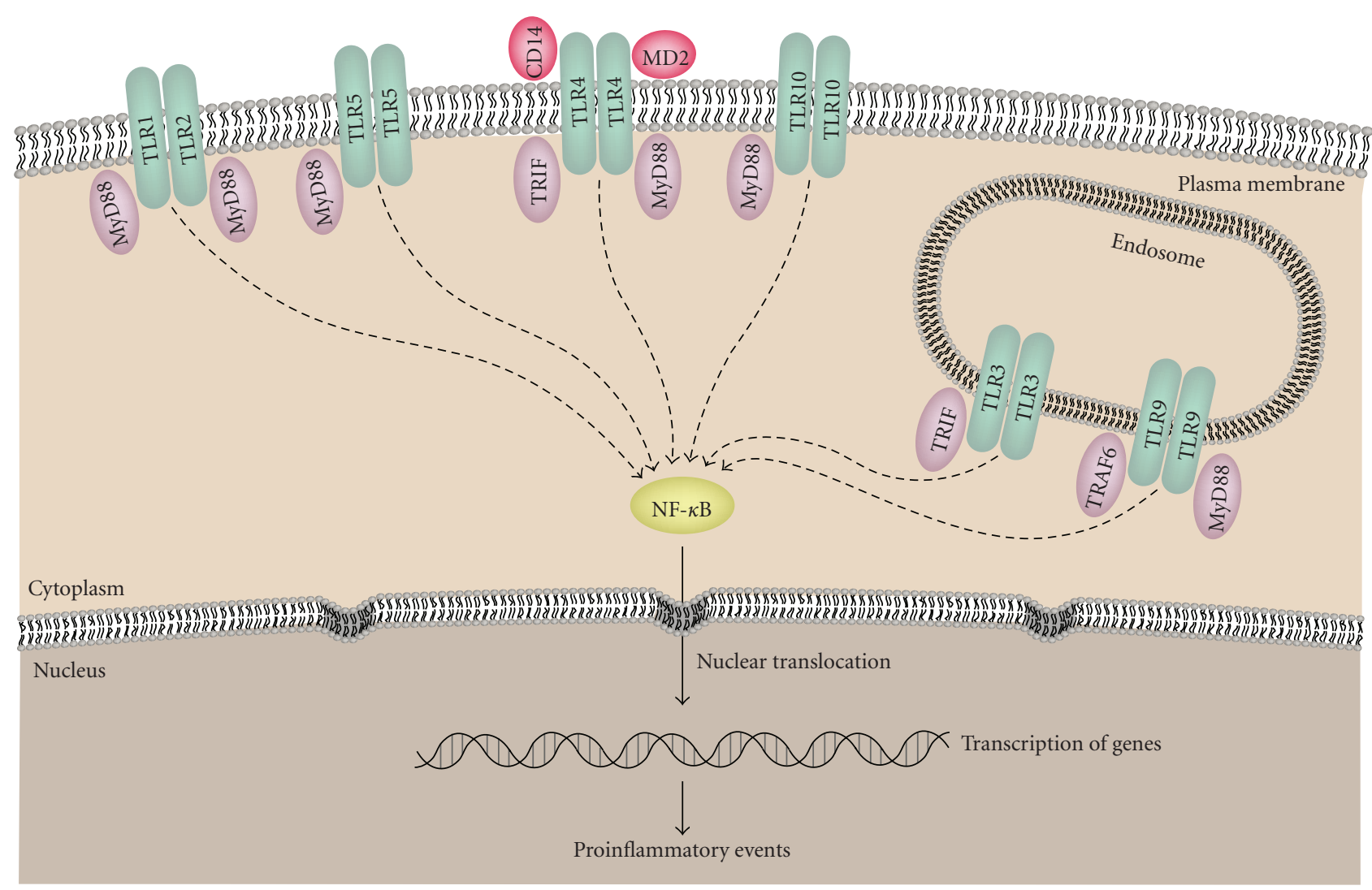

(b)

Figure 1: Continued. 


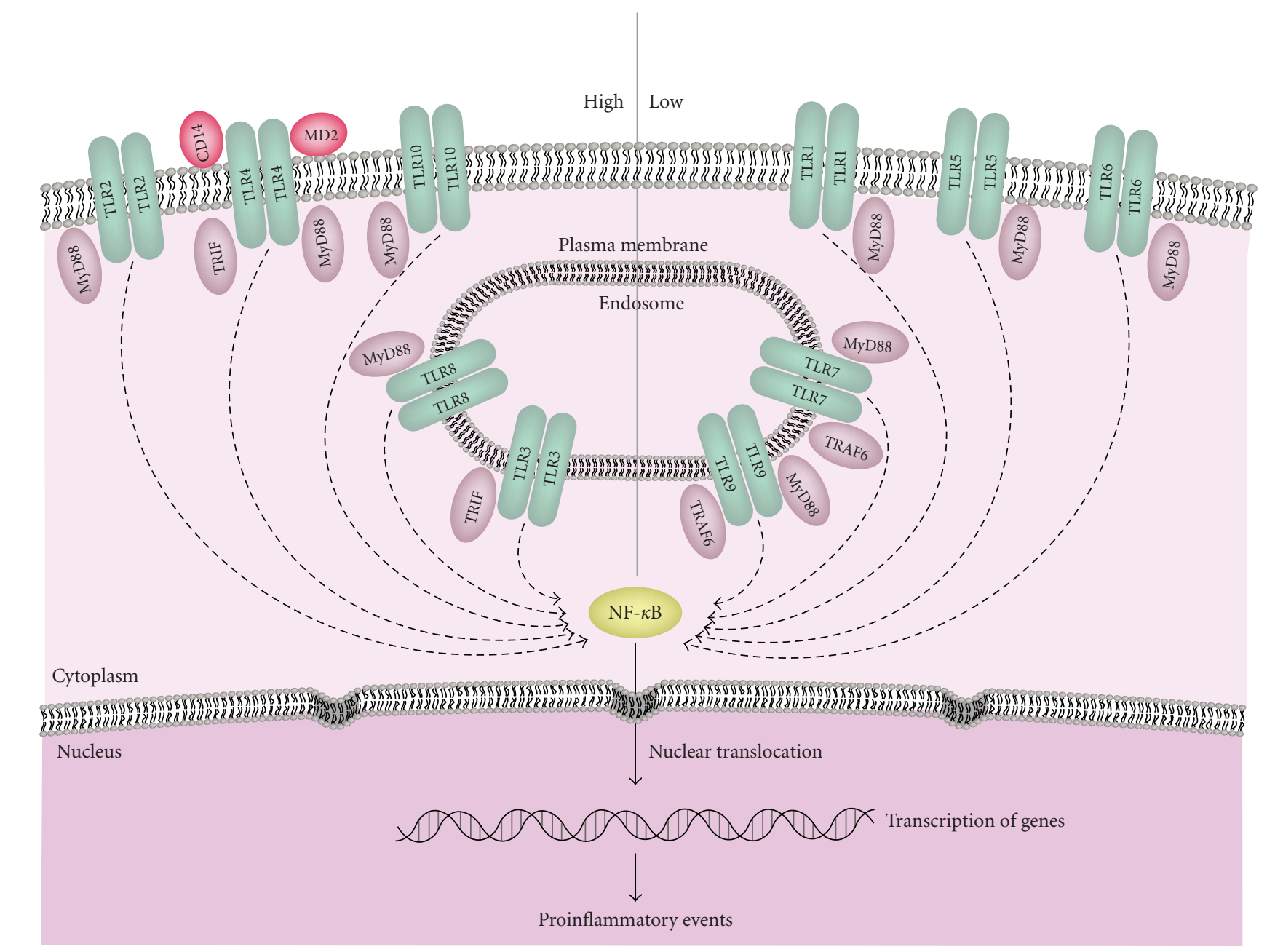

(c)

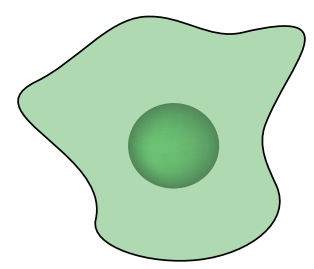

Myeloid derived dendritic cell

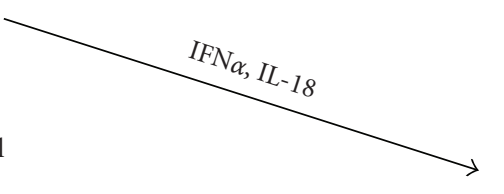

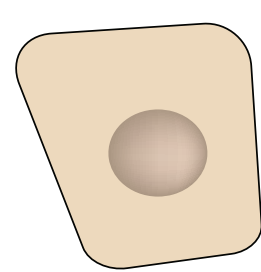

Activated keratinocyte

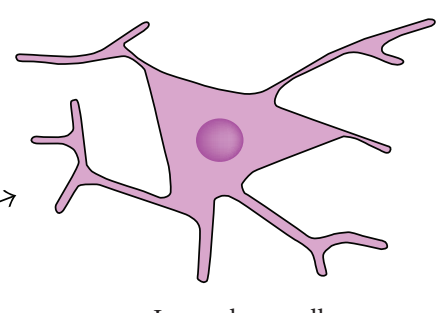

Langerhans cell

(d)

Figure 1: Continued. 


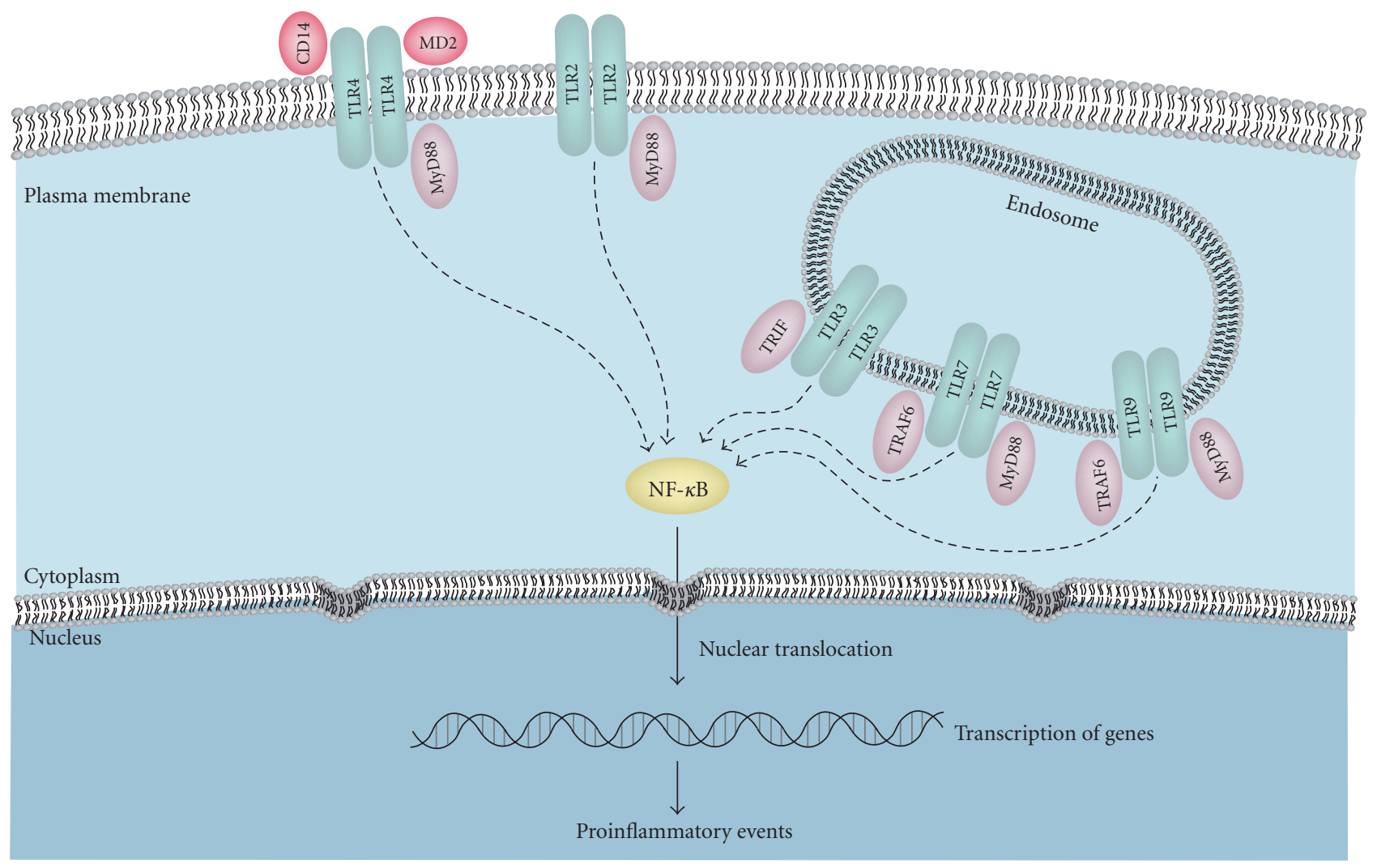

(e)

FIgURE 1: (a) Cross-section of epidermis. Keratinocytes are present throughout the skin; other epidermal cell types include Langerhans cells, melanocytes, and merkel cells. (b) Keratinocytes express TLRs 1, 2, 3, 4, 5, 9, and 10. MD2: TLR4-associated molecule; MyD88: myeloid differentiation factor 88 ; NF- $\kappa$ B: nuclear factor- $\kappa$ B; TRAF-6: TNF receptor-associated factor-6; TRIF: TIR domain-containing adapter protein that induces IFN- $\beta$. (c) Langerhans cells express high levels of TLRs 2, 3, 4, 8, and 10. but express low levels of TLRs 1, 5, 6, 7, and 9. (d) Upon activation, myeloid-derived dendritic cells and to a lesser extent keratinocytes release IFN $\alpha$ and IL-18 which stimulate Langerhans cell maturation. With antigen stimulation the Langerhans cell induces a Th1 response. (e) In response to TLRs 2, 3, 4, 7, and 9 melanocytes initiate proinflammatory events via the illustrated pathways.

TLRs have been linked to dermatological disease and their proposed therapeutic role.

\section{TLRs in Dermatologic Disease}

2.1. Atopic Dermatitis and Allergic Contact Dermatitis. Atopic dermatitis (AD), which affects up to $20 \%$ of the pediatric population, is a chronic inflammatory skin disease characterized by pruritus, eczematous lesions, xerosis, and lichenification. It often forms part of the atopic triad composed of allergic rhinitis, asthma, and eczema [86, 87]. Patients suffering from $\mathrm{AD}$ have greater susceptibility to bacterial, viral, and fungal infections; in fact, $S$. aureus has been associated with its flares and severity $[71,88,89]$. In addition to $S$. aureus, the best characterized infectious agent of $\mathrm{AD}$, strains of Candida species have a strong ability to colonize atopic skin, and viruses such as herpes simplex virus can aggravate the infection and exacerbate the disease [90]. These pathogens express microbial products that stimulate TLR 1, 2, 6, and 9. Recent studies show a strong association between TLR 2 and the symptoms of severe $\mathrm{AD}$ in some populations $[29,30]$. The presence of a single nucleotide polymorphism (SNP) R753Q in the TLR 2 allele has been reported to be associated in patients with severe $\mathrm{AD}$ and whose skin was prone to $S$. aureus infection $[11,91]$. The role of R753Q in AD has been confirmed in the cytokine-based profiling of patients where stimulation of TLR 2 induced altered production of IL-6 and IL-12 [92]. Conversely, a study in a German population found no significant effect of TLR 2 and 4 polymorphisms in relation to susceptibility for $\mathrm{AD}$ [93]. On the other hand, polymorphism C-1237T in the TLR 9 gene has been attributed as the cause for impairment of immunity in some cases of $\mathrm{AD}$ [31]. Taken together, these studies suggest that there is a defect in TLR 2/9. These defects may be genetic (dysfunctional proteins) or functional (attenuation of regulatory pathways) [31, 32, 87]. This defective recognition of pathogenic antigens by TLRs renders greater susceptibility of $\mathrm{AD}$ lesions to various bacterial and viral infections [1]. However, there has been no significant correlation between TLRs 1 and 6 (recognize peptidoglycans, and lipoproteins resp.) and $\mathrm{AD}[30,94$, 95]. Although correlation between TLRs 2, 9 and AD has been reported, another study using monocyte-derived DCs 
found no relation between polymorphism, function of TLR 2-4 with respect to AD [96]. Allergic contact dermatitis (ACD), another eczematous process, is a type IV delayed hypersensitivity reaction seen in the skin typically after sensitization by haptens [97]. The bacterial infections and haptens binding with self-proteins in the skin leads to activation of DCs stimulating a specific autoreactive CD8 response against the epidermis in a TLRs 2-, 4- and 9dependent fashion $[32,98,99]$.

In the case of $\mathrm{AD}$, defective epithelial barrier function, receptor expression, and signalling pathways (altered cytokine production) play a role in disease progression [94, 100-102]. AD and ACD are routinely treated with emollients and topical steroids (for skin flares). Topical calcineurin inhibitors (TCIs), such as pimecrolimus and tacrolimus, are used to treat $\mathrm{AD}$ by modulating $\mathrm{T}$ cell activation [102104]. Pimecrolimus is capable of enhancing the ability of keratinocytes to inhibit pathogen growth. Although pimecrolimus and tacrolimus, have been shown to effectively reduce the symptoms observed compared to placebos, the long-term effects need to be studied in more detail before declaring the treatments safe $[102,103]$. Unfortunately TCIs received a black box warning from the FDA for possible links to carcinogenicity.

Another feasible option for the treatment of severe cases of $\mathrm{AD}$ is phototherapy. In patients with acute flares, ultraviolet A (UVA), ultraviolet B (UVB), or a combination of UVA and UVB therapy may be administered, often with concomitant topical corticosteroids, with a reasonable amount of success [102]. Phototherapy with narrow and broad band UV radiation is noted to be effective in treating $\mathrm{AD}$ as radiation interferes with the immune function and inflammatory process of the local milieu [105-107]. This is relevant to TLRs in the light of findings that TLR 2and 4 mediated production of cytokines plays a role in immunosuppression along with T regulatory cells [50].

2.1.1. Psoriasis. Psoriasis is a common, chronic, relapsing, inflammatory skin disorder with a strong genetic basis. Chronic plaque psoriasis is the most common form of the disease, but other manifestations include guttate, inverse, pustular, erythrodermic, and psoriatic arthritis. Psoriasis is characterized by epidermal hyperproliferation (acanthosis), marked hyperkeratosis with parakeratosis (abnormal maturation), loss of the granular layer, vascular dilatation, and inflammatory cell infiltration. Abnormalities in biochemical, inflammatory, and immunological markers are commonly identified. In the skin of psoriasis patients, there is increased antigen presentation, $\mathrm{T}$ cell proliferation, Th1 and Th17 cytokine production, and angiogenesis. Inappropriate recognition of self-nucleic acids in addition to type I IFNs (IFN$\alpha / \beta)$ production by plasmacytoid DCs (pDCs) can lead to psoriasis [108]. pDCs are an important cell population in this condition, because they are $16 \%$ of the total dermal infiltrate in psoriatic skin lesions whereas they are rare in atopic dermatitis and nonexistent in normal skin [108]. As an example, mechanical injury towards prepsoriatic skin promotes the release of cationic antimicrobial peptide $\left(\mathrm{LL}_{37}\right)$ by keratinocytes [61]. The overexpressed $\mathrm{LL}_{37}$ binds to extracellular self-DNA and forms aggregates that enter pDCs, activate TLR 9, and trigger type I IFN production. Type I IFNs produced by pDCs support myeloid dendritic cell maturation and eventual autoreactive $\mathrm{T}$ cell activation leading to psoriatic skin lesions, in a self-sustaining feedback loop. Concurrently, Th17 cells produce IL-22 and IL-17 which stimulate epidermal hyperplasia and neutrophil recruitment and further enhance inflammation. IFN- $\alpha$ (type 1 IFN) in addition to ssRNA (a simulator of viral infection) also acts as an important trigger for DC activation in psoriasis [109]. Another important growth factor expressed during psoriasis is TGF- $\alpha$, which upregulates TLRs 5 and 9 expression and function in human keratinocytes [110]. Heat shock proteins (i.e., HSP60) are suspected immunogenic proteins that are heavily expressed by epidermal keratinocytes of guttate and plaque psoriasis in comparison to normal skin [111]. HSP60 may subsequently trigger TLR 2 and TLR 4 to stimulate innate and adaptive immunity which develops and/or aggravates psoriasis. The A domain of fibronectin (keratinocyte derived) may act on the TLR 4 pathway in APCs (Langerhans cells) to cause maturation, TNF- $\alpha$ and IL-12 secretion, and antigen presentation to autoreactive $\mathrm{T}$ cells [112]. Interestingly, anti-keratin 16 antibodies are highly concentrated in the serum of psoriasis patients and may be involved in chronic inflammation. Keratinocytes incubated with mouse antikeratin 16 monoclonal, antibodies have increased levels of TLR 2, TLR 4, involucrin, and NF$\kappa \mathrm{B}$ nascent polypeptide-associated complex mRNA [113]. As implied earlier, psoriasis is a $\mathrm{T}$ cell-mediated disease caused in part by activated $\mathrm{T}$ cells interacting with antigenpresenting cells (APCs) in addition to IFN- $\gamma$, IL- 1 , and TNF- $\alpha$ effects $[114,115]$. T cells are distinctly compartmentalized in the different skin layers in psoriatic lesions [116]. $\mathrm{CD}^{+} / \mathrm{Th} 1 \mathrm{~T}$ cells are, for example, located in the upper dermis unlike $\mathrm{CD}^{+} / \mathrm{Th} 1 \mathrm{~T}$ cells that are found in the epidermis [117]. T cells are functionally important since cyclosporine A (an immunosuppressant which binds the cyclophilins of $\mathrm{T}$ lymphocytes), as well as CTLAflg, antiCD4 antibodies, DAB389IL-2, and alefacept (all T cellbased immunomodulators) are highly effective therapies for psoriasis [118-122]. Further support is provided in rare instances of psoriasis transfer to recipients of bone marrow transplants from donors with the disease and similar episodes in xenotransplantation models $[123,124]$.

In regard to TLR expression, keratinocytes in the epidermis constitutively express TLR 1,2 , and 5 . In psoriasis lesions, the expression of TLR 1 and TLR 2 on keratinocytes is further upregulated [62]. Keratinocytes in human psoriatic skin, activated by TLR 2,3 , and 4 ligands exhibited NF- $\kappa$ B nuclear translocation and release of TNF- $\alpha$ and IL-8 [63]. An immunohistochemistry-based profile of psoriatic skin also demonstrates the overexpression of TLR 2 in epidermal and dermal DCs and the enhanced TLR 2 expression in basal layer keratinocytes. It enhanced TLR 4 expression in epidermal and dermal DCs, in addition to accumulation of CD14-positive macrophages [125]. TLRs 7 and 8 signalling have also been implicated in psoriatic exacerbations [112] since imiquimod (a TLR 7/8 agonist) aggravates pathological symptoms. 
Topical immunosuppressive therapies such as topical corticosteroids (i.e., budesonide), pimecrolimus, and tacrolimus are currently used for treating inflammatory skin diseases like atopic dermatitis. They function by suppressing IL-8 and TNF- $\alpha$ mRNA expression and either induce (budesonide) or suppress (tacrolimus) TLR 2 mRNA expression in human keratinocytes $[126,127]$. Although further studies are required, it appears that the clinical use of systemic and topical retinoids helps to control psoriatic inflammation through TLR 2 inhibition [50]. Monomethyl fumarate (fumaric acid ester) is also used as an immunotherapy for psoriasis; markedly, it interferes with LPS signalling through TLR 4 in dendritic cells, inhibits NF- $\kappa$ B activation, decreases IL-12p70 and IL-10 production, and modulates monocytes-derived DC polarization [128]. Furthermore, the TLR 7/8 agonist imiquimod, which was considered a potential therapy, resulted in exacerbated psoriatic lesions, increased DCs infiltration, and elevated IFN- $\gamma$. Another example of potential treatment for psoriasis is the use of anti-inflammatory pharmacologics such as salicylates (as well as other nonsteroidal anti-inflammatory drugs) and parthenolide, which block IkappaB kinase (IKK-1 and IKK2) activity [123]. IKK-1 and IKK-2 are part of the TLR signalling cascade [129]. Although advances are being made and compounds are being clinically tested to target the common signaling pathways of the TLR superfamily to prevent p 38 mitogen-activated protein, NF- $\kappa \mathrm{B}$ activity, and TNF production, caution must be exercised when testing these TLR therapies [129].

2.1.2. Acne Vulgaris. Sebaceous glands are a holocrine gland that secretes sebum [130] formed by the breakdown of glandular cells. Full blown acne manifests in the pilosebaceous follicle and is attributed to increased sebum excretion, sebum lipid alteration, androgen and neuropeptide activities, follicular hyperkeratinization, dsyregulation of cutaneous steroidogenesis, and growth of anaerobic, gram positive Propionibacterium acne (P. acnes) [131, 132]. P. acnes helps sustain inflammation by TLR-mediated induction of cytokines, upregulation of adhesion molecules, and chemokine mediated recruitment of immune cells [133]. Immune cells such as TLR 2 expressing macrophages (perifollicular and peribulbar) tend to surround pilosebaceous follicles in acne lesions; subsequent TLR 2 triggering due to $P$. acnes results in IL-6, IL-8, and IL-12 cytokine production [4]. The proinflammatory response in acne lesions seems to be largely initiated by TLR 2 since the lipid components from the cell wall of $P$. acnes also trigger TLR 2 activation in monocytes [4]; almost all of the TLR 2-expressing cells in acne lesions are derived from CD14 monocytes, suggesting active monocyte recruitment. Monocytes are, in turn, stimulated to produce TNF- $\alpha$, IL-12, IL $1-\beta$, and IL-8 $[4,133]$, which are all major pro-inflammatory cytokines/chemoattractants. Consequently, neutrophils and lymphocytes are attracted to the follicle and exaggerate the observed inflammation. Acne inflammation may also develop because $P$. acnes stimulates the expression of TLR 2, 4 and CD14 in human keratinocytes [27]. Keratinocytes and sebocytes, located near the pilosebaceous unit, may be capable of detecting either pathogens or abnormal lipids [27]. Human SZ95 sebocytes, in particular, express innate immune molecules such as TLR 2, TLR 4, IL-1 $\beta$, IL-6, IL-8 [27], CD1d, and CD14 [131]. As a result of TLR stimulation due to P. acnes, proinflammatory cytokines, chemokines, antimicrobial lipids [132] and antimicrobial peptides (i.e., cathelicidin, defensin1, defensin-2, and psoriasin) [134-137], and human Bdefensin- 2 are produced by these cells [138].

In acne vulgaris, TLR 2 activation can induce robust inflammation as well as cellular apoptosis and tissue injury $[4,28]$. Pharmacological agents have been designed to target inflammation through downregulation of TLR expression and function. Retinoids (a class of vitamin A-derived compounds) bind retinoic acid receptors (RAR) and modulate keratinocyte maturation [139-141]. When primary human monocytes are treated with ATRA (all-trans retinoic acid), TLR 2 and CD14 are downregulated without any change in expression of TLR 1 and 4 [142]. Further, ATRA pre- and cotreatment of monocytes inhibited the ability of TLR $1 / 2$ ligands to trigger cytokine production [142]. In response to $P$. acnes, ATRA-treated monocytes result in cytokine downregulation of IL-12p40, TNF- $\alpha$, and IL-6 [142]. Other antiacneic drugs such as retinoic acid, ZNSO4, doxycycline, nicotinamide, nitroimidazole, retinol, and isotretinoin prevent $\mathrm{O}_{2}{ }^{\bullet}$ production, IL-8 release and keratinocyte apoptosis [143]. Nicotinamide, through interaction with TLR 2 on primary keratinocytes and immortalized HaCaT cells, significantly depresses IL- 8 production (both at mRNA and protein levels) in a dose-dependent manner [144]. It appears that nicotinamide's downregulation of IL-8 is accomplished at the level of transcription by reducing promoter activity. It also inhibits $\mathrm{I} \kappa \mathrm{B}$ degradation (reduced $\mathrm{NF} \kappa \mathrm{B}$ ) and phosphorylation of Jun N-terminal (JNK) MAP kinases and extracellular receptor kinases (ERK) [144]. Current acne therapies exert their effects, at least in part, via TLRs, and newly developing TLR therapies show great potential.

\subsection{Nonmelanoma Skin Cancers. Non-melanoma skin can-} cer (NMSC) is the most common form of cancer worldwide. The two major types of NMSC are basal cell carcinoma (BCC) and squamous cell carcinoma (SCC). Risk factors for the development of NMSC include exposure to high doses of UV and ionizing radiation, chemical carcinogens, immunosuppression, oncogenic viral strains, and genetic predisposition.

BCCs, typically occur in areas of chronic sun exposure are slow growing and rarely metastatize [145-147]. Current therapies consist of surgical removal, radiotherapy, photodynamic therapy, cryotherapy, and intralesional injections of IFN- $\alpha$ [148]. Imiquimod has been administered successfully as a topical immune modulator which induces production of IFN- $\alpha$ and IL-2, leading to a heightened immune response $[33,145,146]$. The effect is therefore expected to be mediated by TLR 7/8. Topical application of $5 \%$ imiquimod has demonstrated efficacy in several clinical trials [33-35, 145, 149-151]. Stary et al. reported observations where topical imiquimod treatment leads to induction of a specific subset of DCs which mediated destruction of BCC lesions [36, 37]. CpG ODNs are composed of repeating unmethylated 
CG regions causing them to resemble bacterial DNA. PF3512676 (a synthetic CpG ODN) is also considered safe and effective in treating BCC [38], which presumably targets TLR 9.

The prevalence of SCC is second only to that of BCC. It is found more commonly in elderly Caucasian men with significant cumulative UV damage [147, 152-154]. Unlike BCCs, SCCs have higher rates of metastasis and tend to be more aggressive in immunosuppressed patients [152]. SCCs are typically treated by surgery, radiation therapy and other chemotherapeutic modalities [154]. Combination therapy consisting of immunosuppressive agents (methotrexate, bleomycin supplemented with 5-bromouracil) did not yield tangible results [155]. A similar method using interferon instead of bromouracil was reported to be much more effective $[154,156]$. As in the case of many skin diseases, imiquimod has been tested for SCC mitigation. TLR 7 and 8 have been manipulated to activate the pro-inflammatory machinery against SCC [154]. The modulation of IL-1, IL6, IL-8, and IL-12 along with promotion of a Th1 response promotes antitumor and antiviral behaviour [154]. Several studies have shown imiquimod to be a viable option to test for efficacy in treatment of SCC [68-70].

2.3. Melanoma. Melanoma is a malignant tumor of melanocytes which causes the majority of skin cancer-related deaths worldwide $[58,157,158]$. Exposure to UV radiation is the main risk factor for the disease [58, 157, 159]. Melanocytes have the ability to help tumor progression in melanoma by responding to hyaluronic acid fragments through TLR 4 by inducing MMP and cytokine production [59]. Although melanocytes have been shown to express other TLRs [25], TLR 9 has been targeted for modulating immune response. A study on a murine lymphoma model which revealed the potential of $\mathrm{CpG}$ ODNs in enhancing immunogenicity of the tumours resulted in exploitation of TLR 9 ligands for melanoma [60, 160].

Many TLR ligands are considered good adjuvant candidates as they can activate dendritic cells. Different TLR 9 agonists are now included in vaccine formulations for human trials. In earlier studies, a vaccine with antigenic peptide and IFA (incomplete Freund's adjuvant) was reported to induce a weak $\mathrm{T}$ cell response. On the contrary, studies with CpG ODNs produced a strong immune response against the Hepatitis B virus [161]. In clinical studies using CpG 7909 (a variant of CpG ODNs) in combination with a melanoma peptide, the vaccine resulted in 10-fold greater specific CD8 T cells compared to peptide alone $[60,161$, 162]. Recently a variant of CpG 7909 named PF-3512676 was used [163] in a phase II clinical trial which yielded promising results and had a moderate safety profile but displayed some very rare adverse events. In all, TLR 9 targeting appears to be a viable option in melanoma treatment [164]. In addition, imiquimod (a TLR 7 agonist) was used to harness the potential TLR 7-based treatment for melanoma. Imiquimod is effective in both activating dendritic cells and producing tumor-specific cytotoxic T cells that arrest disease progression [165].

\subsection{Therapeutic Drugs}

2.4.1. Imidazoquinolinamines-Immune Modulators. Imidazoquinoline compounds (ICs) have similar structure to nucleosides found in all living organisms. They were initially produced and tested as antiallergic drugs in rats, and were reported to be reasonably effective [166]. After extensive studies, the potential of ICs to stimulate secretion of proinflammatory cytokines was finally discovered [167, 168]. Toll like receptor $7 / 8$ directs a cascade of events which leads to the release of specific cytokines [169]. Imiquimod and resiquimod are two compounds that are efficient at activating the immune system [170]. Both compounds induce secretion of IFN- $\alpha$, TNF- $\alpha$, IL-6, and other proinflammatory cytokines from APCs such as resident B cells, pDCs, and monocytes [170-173]. They achieve this response by activating TLR pathways and promoting nuclear transmigration of transcription factors like $\mathrm{NF} \kappa \mathrm{B}$ and activator protein 1 (AP1). Imiquimod, the more extensively studied analogue, is known to enhance apoptotic pathways in cancer cells. It binds to the high affinity adenosine receptors and suppresses its ability to regulate negative feedback [168]. Resiquimod, a chemically related compound, exhibited 100fold greater ability to stimulate apoptosis in preliminary studies [170]. Unfortunately, unlike imiquimod, resiquimod has not been studied extensively [50]. At the time of their discovery, imidazoquinolines were hypothesized to effectively treat Kaposi's sarcoma, human papillomavirus (HPV) and other infections [170]. Initially generated to be an antiviral agent, it was quickly utilized for its expanding therapeutic potential. Imiquimod was one of the first of such analogues to be authorized for treatment of genital warts caused by HPV $[6,26]$. Imiquimod has also been used to activate the immune system in many diseases like actinic keratoses [50], BCC [35, 149-151], SCC [70, 154], and melanoma $[58,60,165,174-176]$. Two other immunomodulators which function through TLR 7, loxoribine, and bropirimine have also been used [6]. Loxoribine, a guanosine ribonucleoside, enhances production of IFN and activates NK cells and B cells [50, 177, 178]. Bropirimine, an aryl pyrimidinone class of antineoplastic compounds, has a similar effect to loxoribine and is currently in clinical studies for treatment of carcinomas [50, 179].

2.4.2. Calcineurin Inhibitors-Immune Suppressors. Calcineurin inhibitors are potent suppressors of the T cell mediated immune response due to their ability to inactivate the serine protease calcineurin. This prevents nuclear translocation of (NFAT nuclear factor of activated T cells), thereby inhibiting the synthesis of pro-inflammatory cytokines in $\mathrm{T}$ cells $[104,171]$. Pimecrolimus and tacrolimus are ascomycin macrolactam derivatives that are categorised as inhibitors of calcium-dependent phosphatase. In the early stages of $\mathrm{AD}$, the topical application of $1 \%$ pimecrolimus was deemed more effective than topical steroids [102, 171]. Different formulations of the drug are being tested for efficacy in psoriasis, vitiligo, and other skin diseases [127, 171, 180]. As previously mentioned, pimecrolimus has been shown to enhance the ability of keratinocytes to fight infection 
Table 1: Toll like Receptors in dermatologic disease.

\begin{tabular}{|c|c|c|c|}
\hline Disease/infection & Toll like receptor associated & Associated function with the disease & References \\
\hline Acne vulgaris & TLR 2, 4, CD14 & $\begin{array}{l}\text { TLR upregulation with eventual } \\
\text { exacerbation of the disease }\end{array}$ & {$[4,27,28]$} \\
\hline Atopic dermatitis & TLR 2, 9 & $\begin{array}{l}\text { TLR polymorphism leading to } \\
\text { increased susceptibility }\end{array}$ & [29-32] \\
\hline Basal cell carcinoma & $\operatorname{TLR} 7,8,9$ & $\begin{array}{l}\text { Exacerbation of disease, target for } \\
\text { therapy }\end{array}$ & {$[33-38]$} \\
\hline $\begin{array}{l}\text { Behçet's } \\
\text { disease-vasculitis }\end{array}$ & TLR 4, 6 & $\begin{array}{l}\text { TLR } 4 \text { polymorphism leads to } \\
\text { increased susceptibility, differential } \\
\text { regulation of TLR } 6 \text { helps in } \\
\text { progression of disease }\end{array}$ & {$[39,40]$} \\
\hline $\begin{array}{l}\text { Borreliosis/Lyme } \\
\text { disease }\end{array}$ & TLR $1 / 2$ (heterodimers), 4,6 & $\begin{array}{l}\text { TLR upregulation with eventual } \\
\text { exacerbation of the disease }\end{array}$ & {$[41,42]$} \\
\hline Candida albicans & TLR 2, 4-CD14, 6 & $\begin{array}{l}\text { TLR function and signalling leads } \\
\text { to disease progression }\end{array}$ & {$[43-45]$} \\
\hline $\begin{array}{l}\text { Cutaneous graft } \\
\text { versus host disease }\end{array}$ & TLR 4 & $\begin{array}{l}\text { Exacerbation disease in response to } \\
\text { LPS }\end{array}$ & {$[46]$} \\
\hline $\begin{array}{l}\text { Herpes } \\
\text { simplex/Varicella } \\
\text { zoster }\end{array}$ & TLR 2, 3, 9 & $\begin{array}{l}\text { Select TLR } 2 \text { polymorphism } \\
\text { associated with disease severity, } \\
\text { TLR } 3 \text { and } 9 \text { help in viral clearance }\end{array}$ & {$[47-49]$} \\
\hline Leprosy & $\operatorname{TLR} 1,2$ & $\begin{array}{l}\text { TLR function and signalling lead to } \\
\text { disease progression }\end{array}$ & {$[21,50-52]$} \\
\hline Lichen planus & TLR 9 & $\begin{array}{l}\text { TLR upregulation with eventual } \\
\text { exacerbation of the disease }\end{array}$ & {$[53,54]$} \\
\hline Lupus erythematosus & $\operatorname{TLR} 3,7,9$ & $\begin{array}{l}\text { TLR } 7 \text { upregulation and TLR } 3^{*} \text {, } \\
\text { TLR } 9 \text { function helps to create } \\
\text { autoreactive cells }\end{array}$ & {$[55-57]$} \\
\hline Melanoma & $\operatorname{TLR} 4,7,9$ & $\begin{array}{l}\text { TLR } 4 \text { exacerbates disease TLR } \\
\text { 7,9-targetted for immune } \\
\text { modulation }\end{array}$ & {$[25,58-60]$} \\
\hline Psoriasis & TLR $1-4,5,9$ & $\begin{array}{l}\text { TLRs upregulated and help in } \\
\text { creation of autoreactive T cells }\end{array}$ & {$[17,61-63]$} \\
\hline Sarcoidosis & TLR 2, 4 & $\begin{array}{l}\text { TLRs polymorphism associated } \\
\text { with disease severity }\end{array}$ & {$[64-66]$} \\
\hline Scleroderma & TLR 4 & $\begin{array}{l}\text { TLR function and signalling lead to } \\
\text { disease progression }\end{array}$ & {$[67]$} \\
\hline $\begin{array}{l}\text { Squamous cell } \\
\text { carcinoma }\end{array}$ & TLR 7, 8 & $\begin{array}{l}\text { Exacerbation of disease, being } \\
\text { studied to target for therapy* }\end{array}$ & {$[68-70]$} \\
\hline Staph. Aureus & TLR 2, 6 & $\begin{array}{l}\text { TLR } 2 \text { polymorphism associated } \\
\text { with severity*, TLR } 2 / 6 \text { function } \\
\text { and signalling lead to disease } \\
\text { progression }\end{array}$ & {$[71,72]$} \\
\hline $\begin{array}{l}\text { Stevens-Johnson } \\
\text { syndrome/Toxic } \\
\text { epidermal necrolysis }\end{array}$ & TLR 3 & $\begin{array}{l}\text { TLR polymorphism linked to } \\
\text { disease severity }\end{array}$ & {$[73]$} \\
\hline Syphilis & TLR 2, 4/5 (heterodimer) & TLRs activate the immune system & {$[26,50,74]$} \\
\hline Vaccinia & TLR $2,3,4$ & $\begin{array}{l}\text { TLRs help in viral clearance but are } \\
\text { targeted by viral products which } \\
\text { suppress host defense }\end{array}$ & {$[71,75,76]$} \\
\hline $\begin{array}{l}\text { Verruca and } \\
\text { Molluscum } \\
\text { Contagiosum }\end{array}$ & TLR 3,7,9 & $\begin{array}{l}\text { TLR 3, } 9 \text { help in immune activation, } \\
\text { TLR 7* possible association with } \\
\text { disease exacerbation, proposed } \\
\text { target for therapy }\end{array}$ & {$[77-80]$} \\
\hline $\begin{array}{l}\text { Yersinia } s p p \text { - the } \\
\text { plague }\end{array}$ & TLR 2, 4-CD14 & $\begin{array}{l}\text { Pathogen exploits TLR pathway to } \\
\text { survive }\end{array}$ & {$[50,81,82]$} \\
\hline
\end{tabular}

* proposed association subject to further investigation. 
when coadministered with TLR 2/6 ligands [104]. Similar to pimecrolimus in structure and function, tacrolimus is utilized for identical purposes, albeit at lower concentrations $(0.03 \%$ to $0.1 \%)$. Tacrolimus appears safe for administration at $0.1 \%$ for treatment of $\mathrm{AD}$ but with certain adverse side effects, such as burning sensation and pruritus observed in a small minority [103]. The drug is under trial for treatment of other diseases such as seborrheic and contact dermatitis, systemic lupus erythematosus, and bullous pemphigoid $[171,180]$. Sirolimus or rapamycin is a macrolactam-like compound which inhibits IL-2 synthesis and cell cycle pathways [181]. Sirolimus, if injected along with cyclosporine A, prevents the progression of UV-mediated skin cancer [182]. The drug is under consideration in combination with other drugs for treatment of skin malignancies, hepatocarcinomas, lupus, psoriasis, dermatomyositis, graft rejection, and a genetic disorder, pachyonychia congenital [180, 183$188]$.

Table 1 lists a selected group of skin diseases and the different TLRs affiliated with each disease. The TLRs associated can either activate the immune system or promote disease progression as indicated.

\section{Conclusion}

Toll like receptors represent a conserved group of receptors which help the immune system to function properly. Different TLRs are associated with an array of skin diseases (Table 1). TLR agonists and antagonists have great potential for the treatment of allergic and inflammatory diseases. More research must discern the relationship between specific TLRs and the corresponding disease in order to harness the therapeutic potential of TLR ligands. Although studies have proven that TLR agonists like CpG can induce a robust immune response, the efficacy of the vaccines, optimization of dosage, long-term effects, and augmentation requires further study $[162,172]$.

\section{Acknowledgments}

The authors would like to thank Jennifer Tran for her illustrations and reviewing the paper. We would also like to thank Cory Olson for reviewing the paper.

\section{References}

[1] L. S. Miller, "Toll-like receptors in skin," Advances in Dermatology, vol. 24, pp. 71-87, 2008.

[2] R. Medzhitov, "Toll-like receptors and innate immunity," Nature Reviews Immunology, vol. 1, no. 2, pp. 135-145, 2001.

[3] M. G. Netea, C. van der Graaf, J. W. M. Van der Meer, and B. J. Kullberg, "Toll-like receptors and the host defense against microbial pathogens: bringing specificity to the innateimmune system," Journal of Leukocyte Biology, vol. 75, no. 5, pp. 749-755, 2004.

[4] J. Kim, M.-T. Ochoa, S. R. Krutzik et al., "Activation of Toll-like receptor 2 in acne triggers inflammatory cytokine responses," Journal of Immunology, vol. 169, no. 3, pp. 15351541, 2002.
[5] A. Iwasaki and R. Medzhitov, "Toll-like receptor control of the adaptive immune responses," Nature Immunology, vol. 5, no. 10, pp. 987-995, 2004.

[6] K. Takeda, T. Kaisho, and S. Akira, "Toll-like receptors," Annual Review of Immunology, vol. 21, pp. 335-376, 2003.

[7] R. Shimazu, S. Akashi, H. Ogata et al., "MD-2, a molecule that confers lipopolysaccharide responsiveness on toll- like receptor 4," Journal of Experimental Medicine, vol. 189, no. 11, pp. 1777-1782, 1999.

[8] S. D. Wright, P. S. Tobias, R. J. Ulevitch, and R. A. Ramos, "Lipopolysaccharide (LPS) binding protein opsonizes LPSbearing particles for recognition by a novel receptor on macrophages," Journal of Experimental Medicine, vol. 170, no. 4, pp. 1231-1241, 1989.

[9] T. Kaisho and S. Akira, "Toll-like receptor function and signaling," Journal of Allergy and Clinical Immunology, vol. 117, no. 5, pp. 979-987, 2006.

[10] K. J. Loniewski, S. Patial, and N. Parameswaran, "Sensitivity of TLR4- and -7-induced NF $\kappa$ B1 p105-TPL2-ERK pathway to TNF-receptor-associated-factor- 6 revealed by RNAi in mouse macrophages," Molecular Immunology, vol. 44, no. 15, pp. 3715-3723, 2007.

[11] V. Petry and A. A. Gaspari, "Toll-like receptors and dermatology," International Journal of Dermatology, vol. 48, no. 6, pp. 558-570, 2009.

[12] M. Schnare, G. M. Barton, A. C. Holt, K. Takeda, S. Akira, and R. Medzhitov, "Toll-like receptors control activation of adaptive immune responses," Nature Immunology, vol. 2, no. 10, pp. 947-950, 2001.

[13] M. Kobayashi, R. Yoshiki, J. Sakabe, K. Kabashima, M. Nakamura, and Y. Tokura, "Expression of toll-like receptor 2, NOD2 and dectin-1 and stimulatory effects of their ligands and histamine in normal human keratinocytes," British Journal of Dermatology, vol. 160, no. 2, pp. 297-304, 2009.

[14] P. I. Song, Y.-M. Park, T. Abraham et al., "Human keratinocytes express functional CD14 and toll-like receptor 4," Journal of Investigative Dermatology, vol. 119, no. 2, pp. 424432, 2002.

[15] M. Mempel, V. Voelcker, G. Köllisch et al., "Toll-like receptor expression in human keratinocytes: nuclear factor $\kappa \mathrm{B}$ controlled gene activation by Staphylococcus aureus is Toll-like receptor 2 but not Toll-like receptor 4 or platelet activating factor receptor dependent," Journal of Investigative Dermatology, vol. 121, no. 6, pp. 1389-1396, 2003.

[16] B. S. Baker, J.-M. Ovigne, A. V. Powles, S. Corcoran, and L. Fry, "Normal keratinocytes express Toll-like receptors (TLRs) 1,2 and 5: modulation of TLR expression in chronic plaque psoriasis," British Journal of Dermatology, vol. 148, no. 4, pp. 670-679, 2003.

[17] L. S. Miller, O. E. Sørensen, P. T. Liu et al., "TGF- $\alpha$ regulates TLR expression and function on epidermal keratinocytes," Journal of Immunology, vol. 174, no. 10, pp. 6137-6143, 2005.

[18] G. Köllisch, B. N. Kalali, V. Voelcker et al., "Various members of the Toll-like receptor family contribute to the innate immune response of human epidermal keratinocytes," Immunology, vol. 114, no. 4, pp. 531-541, 2005.

[19] M. C. Lebre, A. M. G. van der Aar, L. Van Baarsen et al., "Human keratinocytes express functional toll-like receptor 3, 4, 5, and 9," Journal of Investigative Dermatology, vol. 127, no. 2, pp. 331-341, 2007.

[20] A. Pivarcsi, L. Bodai, B. Réthi et al., "Expression and function of Toll-like receptors 2 and 4 in human keratinocytes," International Immunology, vol. 15, no. 6, pp. 721-730, 2003. 
[21] J. E. McInturff, R. L. Modlin, and J. Kim, "The role of toll-like receptors in the pathogenesis and treatment of dermatological disease," Journal of Investigative Dermatology, vol. 125, no. 1, pp. 1-8, 2005.

[22] Y. Lee, H. Kim, S. Kim, K. H. Kim, and J. H. Chung, "Activation of toll-like receptors 2, 3 or 5 induces matrix metalloproteinase-1 and -9 expression with the involvement of MAPKs and NF-kappaB in human epidermal keratinocytes," Experimental Dermatology, vol. 19, no. 8, pp. 44-49, 2010.

[23] M. C. Lebre, J. C. Antons, P. Kalinski et al., "Double-stranded RNA-exposed human keratinocytes promote Th1 responses by inducing a type- 1 polarized phenotype in dendritic cells: role of keratinocyte-derived tumor necrosis factor $\alpha$, type I interferons, and interleukin-18," Journal of Investigative Dermatology, vol. 120, no. 6, pp. 990-997, 2003.

[24] C. N. Renn, D. J. Sanchez, M. T. Ochoa et al., "TLR activation of langerhans cell-like dendritic cells triggers an antiviral immune response," Journal of Immunology, vol. 177, no. 1, pp. 298-305, 2006.

[25] N. Yu, S. Zhang, F. Zuo, K. Kang, M. Guan, and L. Xiang, "Cultured human melanocytes express functional Toll-like receptors 2-4, 7 and 9," Journal of Dermatological Science, vol. 56, no. 2, pp. 113-120, 2009.

[26] M. Mempel, B. N. Kalali, M. Ollert, and J. Ring, "Toll-like receptors in dermatology," Dermatologic Clinics, vol. 25, no. 4, pp. 531-540, 2007.

[27] A. Koreck, A. Pivarcsi, A. Dobozy, and L. Kemény, "The role of innate immunity in the pathogenesis of acne," Dermatology, vol. 206, no. 2, pp. 96-105, 2003.

[28] A. J. Chong, A. Shimamoto, C. R. Hampton et al., "Tolllike receptor 4 mediates ischemia/reperfusion injury of the heart," Journal of Thoracic and Cardiovascular Surgery, vol. 128 , no. 2, pp. 170-179, 2004.

[29] H. Hasannejad, R. Takahashi, M. Kimishima, K. Hayakawa, and T. Shiohara, "Selective impairment of Toll-like receptor 2-mediated proinflammatory cytokine production by monocytes from patients with atopic dermatitis," Journal of Allergy and Clinical Immunology, vol. 120, no. 1, pp. 69-75, 2007.

[30] D.-Y. Oh, R. R. Schumann, L. Hamann, K. Neumann, M. Worm, and G. Heine, "Association of the toll-like receptor 2 A-16934T promoter polymorphism with severe atopic dermatitis," Allergy, vol. 64, no. 11, pp. 1608-1615, 2009.

[31] N. Novak, C.-F. Yu, C. Bussmann et al., "Putative association of a TLR9 promoter polymorphism with atopic eczema," Allergy, vol. 62, no. 7, pp. 766-772, 2007.

[32] H. Jin, L. Kumar, C. Mathias et al., "Toll-like receptor 2 is important for the $\mathrm{T}_{\mathrm{H}}^{1}$ response to cutaneous sensitization," Journal of Allergy and Clinical Immunology, vol. 123, no. 4, pp. 875-882, 2009.

[33] J. K. Geisse, P. Rich, A. Pandya et al., "Imiquimod 5\% cream for the treatment of superficial basal cell carcinoma: a double-blind, randomized, vehicle-controlled study," Journal of the American Academy of Dermatology, vol. 47, no. 3, pp. 390-398, 2002.

[34] E. Stockfleth, U. Trefzer, C. Garcia-Bartels, T. Wegner, T. Schmook, and W. Sterry, "The use of Toll-like receptor-7 agonist in the treatment of basal cell carcinoma: an overview," British Journal of Dermatology, Supplement, vol. 149, no. 66, pp. 53-56, 2003.

[35] R. Dummer, M. Urosevic, W. Kempf, K. Hoek, J. Hafner, and G. Burg, "Imiquimod in basal cell carcinoma: how does it work?" British Journal of Dermatology, Supplement, vol. 149, no. 66 , supplement, pp. 57-58, 2003.
[36] G. Stary, C. Bangert, M. Tauber, R. Strohal, T. Kopp, and G. Stingl, "Tumoricidal activity of TLR7/8-activated inflammatory dendritic cells," Journal of Experimental Medicine, vol. 204, no. 6, pp. 1441-1451, 2007.

[37] L. C. Zaba, J. G. Krueger, and M. A. Lowes, "Resident and "inflammatory" dendritic cells in human skin," Journal of Investigative Dermatology, vol. 129, no. 2, pp. 302-308, 2009.

[38] M. A. Hofmann, C. Kors, H. Audring, P. Walden, W. Sterry, and U. Trefzer, "Phase 1 evaluation of intralesionally injected TLR9-agonist PF-3512676 in patients with basal cell carcinoma or metastatic melanoma," Journal of Immunotherapy, vol. 31, no. 5, pp. 520-527, 2008.

[39] Y. Horie, A. Meguro, M. Ota et al., "Association of TLR4 polymorphisms with Behçet's disease in a Korean population," Rheumatology, vol. 48, no. 6, pp. 638-642, 2009.

[40] S. Yavuz, Y. Elbir, A. Tulunay, E. Eksioglu-Demiralp, and H. Direskeneli, "Differential expression of toll-like receptor 6 on granulocytes and monocytes implicates the role of microorganisms in Behcet's disease etiopathogenesis," Rheumatology International, vol. 28, no. 5, pp. 401-406, 2008.

[41] J. C. Salazar, C. D. Pope, T. J. Sellati et al., "Coevolution of markers of innate and adaptive immunity in skin and peripheral blood of patients with erythema migrans," Journal of Immunology, vol. 171, no. 5, pp. 2660-2670, 2003.

[42] Y. Bulut, E. Faure, L. Thomas, O. Equils, and M. Arditi, "Cooperation of Toll-like receptor 2 and 6 for cellular activation by soluble tuberculosis factor and Borrelia burgdorferi outer surface protein a lipoprotein: role of Toll-interacting protein and IL-1 receptor signaling molecules in Toll-like receptor 2 signaling," Journal of Immunology, vol. 167, no. 2, pp. 987-994, 2001.

[43] H. Tada, E. Nemoto, H. Shimauchi et al., "Saccharomyces cerevisiae- and Candida albicans-derived mannan induced production of tumor necrosis factor alpha by human monocytes in a CD14- and Toll-like receptor 4-dependent manner," Microbiology and Immunology, vol. 46, no. 7, pp. 503-512, 2002.

[44] T. Jouault, S. Ibata-Ombetta, O. Takeuchi et al., "Candida albicans phospholipomannan is sensed through toll-like receptors," Journal of Infectious Diseases, vol. 188, no. 1, pp. 165-172, 2003.

[45] M. G. Netea, N. A. R. Gow, C. A. Munro et al., "Immune sensing of Candida albicans requires cooperative recognition of mannans and glucans by lectin and Toll-like receptors," Journal of Clinical Investigation, vol. 116, no. 6, pp. 16421650, 2006.

[46] K. R. Cooke, A. Gerbitz, J. M. Crawford et al., "LPS antagonism reduces graft-versus-host disease and preserves graftversus-leukemia activity after experimental bone marrow transplantation," Journal of Clinical Investigation, vol. 107, no. 12, pp. 1581-1589, 2001.

[47] P.-Y. Bochud, A. S. Magaret, D. M. Koelle, A. Aderem, and A. Wald, "Polymorphisms in TLR2 are associated with increased viral shedding and lesional rate in patients with genital herpes simplex virus type 2 infection," Journal of Infectious Diseases, vol. 196, no. 4, pp. 505-509, 2007.

[48] S.-Y. Zhang, E. Jouanguy, S. Ugolini et al., "TLR3 deficiency in patients with herpes simplex encephalitis," Science, vol. 317, no. 5844, pp. 1522-1527, 2007.

[49] A. Sato, M. M. Linehan, and A. Iwasaki, "Dual recognition of herpes simplex viruses by TLR2 and TLR9 in dendritic cells," Proceedings of the National Academy of Sciences of the United States of America, vol. 103, no. 46, pp. 17343-17348, 2006. 
[50] S. S. W. Kang, L. S. Kauls, and A. A. Gaspari, "Toll-like receptors: applications to dermatologic disease," Journal of the American Academy of Dermatology, vol. 54, no. 6, pp. 951983, 2006.

[51] S. R. Krutzik, M. T. Ochoa, P. A. Sieling et al., "Activation and regulation of Toll-like receptors 2 and 1 in human leprosy," Nature Medicine, vol. 9, no. 5, pp. 525-532, 2003.

[52] R. B. Oliveira, M. T. Ochoa, P. A. Sieling et al., "Expression of toll-like receptor 2 on human schwann cells: a mechanism of nerve damage in leprosy," Infection and Immunity, vol. 71, no. 3, pp. 1427-1433, 2003.

[53] S. Meller, M. Gilliet, and B. Homey, "Chemokines in the pathogenesis of lichenoid tissue reactions," Journal of Investigative Dermatology, vol. 129, no. 2, pp. 315-319, 2009.

[54] J. Li, J. Chen, Z. Tan, H. Liu, and Z. Liu, "Expression of TLR9 and its mRNA in the lesions of lichen planus," Journal of Huazhong University of Science and Technology, vol. 27, no. 2, pp. 203-205, 2007.

[55] P. Pisitkun, J. A. Deane, M. J. Difilippantonio, T. Tarasenko, A. B. Satterthwaite, and S. Bolland, "Autoreactive B cell responses to RNA-related antigens due to TLR7 gene duplication," Science, vol. 312, no. 5780, pp. 1669-1672, 2006.

[56] E. L. Greidinger, Y. Zang, K. Jaimes et al., "A murine model of mixed connective tissue disease induced with U1 small nuclear RNP autoantigen," Arthritis and Rheumatism, vol. 54, no. 2, pp. 661-669, 2006.

[57] T. K. Means and A. D. Luster, "Toll-like receptor activation in the pathogenesis of systemic lupus erythematosus," Annals of the New York Academy of Sciences, vol. 1062, pp. 242-251, 2005.

[58] J. Wenzel, D. Tormo, and T. Tüting, "Toll-like receptoragonists in the treatment of skin cancer: history, current developments and future prospects," Handbook of Experimental Pharmacology, no. 183, pp. 201-220, 2008.

[59] V. Voelcker, C. Gebhardt, M. Averbeck et al., "Hyaluronan fragments induce cytokine and metalloprotease upregulation in human melanoma cells in part by signalling via TLR4," Experimental Dermatology, vol. 17, no. 2, pp. 100-107, 2008.

[60] L. Fang, A. S. Lonsdorf, and S. T. Hwang, "Immunotherapy for advanced melanoma," Journal of Investigative Dermatology, vol. 128, no. 11, pp. 2596-2605, 2008.

[61] M. Gilliet and R. Lande, "Antimicrobial peptides and selfDNA in autoimmune skin inflammation," Current Opinion in Immunology, vol. 20, no. 4, pp. 401-407, 2008.

[62] B. S. Baker, J.-M. Ovigne, A. V. Powles, S. Corcoran, and L. Fry, "Normal keratinocytes express Toll-like receptors (TLRs) 1, 2 and 5: modulation of TLR expression in chronic plaque psoriasis," British Journal of Dermatology, vol. 148, no. 4, pp. 670-679, 2003.

[63] É. Begon, L. Michel, B. Flageul et al., "Expression, subcellular localization and cytokinic modulation of Toll-like receptors (TLRs) in normal human keratinocytes: TLR2 up-regulation in psoriatic skin," European Journal of Dermatology, vol. 17, no. 6, pp. 497-506, 2007.

[64] S. Pabst, G. Baumgarten, A. Stremmel et al., "Toll-like receptor (TLR) 4 polymorphisms are associated with a chronic course of sarcoidosis," Clinical and Experimental Immunology, vol. 143, no. 3, pp. 420-426, 2006.

[65] M. Veltkamp, P. A. H. M. Wijnen, C. H. M. Van Moorsel et al., "Linkage between Toll-like receptor (TLR) 2 promotor and intron polymorphisms: functional effects and relevance to sarcoidosis," Clinical and Experimental Immunology, vol. 149, no. 3, pp. 453-462, 2007.
[66] M. Wikén, J. Grunewald, A. Eklund, and J. Wahlström, "Higher monocyte expression of TLR2 and TLR4, and enhanced pro-inflammatory synergy of TLR2 with NOD2 stimulation in sarcoidosis," Journal of Clinical Immunology, vol. 29, no. 1, pp. 78-89, 2009.

[67] A. Yoshizaki, Y. Iwata, K. Komura et al., "CD19 regulates skin and lung fibrosis via toll-like receptor signaling in a model of bleomycin-induced scleroderma," American Journal of Pathology, vol. 172, no. 6, pp. 1650-1663, 2008.

[68] K. Peris, T. Micantonio, M. C. Fargnoli, G. P. Lozzi, and S. Chimenti, "Imiquimod $5 \%$ cream in the treatment of Bowen's disease and invasive squamous cell carcinoma," Journal of the American Academy of Dermatology, vol. 55, no. 2, pp. 324-327, 2006.

[69] G. K. Patel, R. Goodwin, M. Chawla et al., "Imiquimod 5\% cream monotherapy for cutaneous squamous cell carcinoma in situ (Bowen's disease): a randomized, double-blind, placebo-controlled trial," Journal of the American Academy of Dermatology, vol. 54, no. 6, pp. 1025-1032, 2006.

[70] S. J. Huang, D. Hijnen, G. F. Murphy et al., "Imiquimod enhances ifn- $\gamma$ production and effector function of $\mathrm{T}$ cells infiltrating human squamous cell carcinomas of the skin," Journal of Investigative Dermatology, vol. 129, no. 11, pp. 2676-2685, 2009.

[71] Y. Lai and R. L. Gallo, "Toll-like receptors in skin infections and inflammatory diseases," Infectious Disorders-drug Targets, vol. 8, no. 3, pp. 144-155, 2008.

[72] N. W. J. Schröder, S. Morath, C. Alexander et al., "Lipoteichoic acid (LTA) of Streptococcus pneumoniae and Staphylococcus aureus activates immune cells via Toll-like receptor (TLR)-2, lipopolysaccharide-binding protein (LBP), and CD14, whereas TLR-4 and MD-2 are not involved," The Journal of Biological Chemistry, vol. 278, no. 18, pp. 1558715594, 2003.

[73] M. Ueta, C. Sotozono, T. Inatomi et al., "Toll-like receptor 3 gene polymorphisms in Japanese patients with StevensJohnson syndrome," British Journal of Ophthalmology, vol. 91, no. 7, pp. 962-965, 2007.

[74] S. B. Mizel, A. N. Honko, M. A. Moors, P. S. Smith, and A. P. West, "Induction of macrophage nitric oxide production by gram-negative flagellin involves signaling via heteromeric Toll-like receptor 5/Toll-like receptor 4 complexes," Journal of Immunology, vol. 170, no. 12, pp. 6217-6223, 2003.

[75] A. Bowie and L. A. J. O'Neill, “The interleukin-1 receptor/Toll-like receptor superfamily: signal generators for pro-inflammatory interleukins and microbial products," Journal of Leukocyte Biology, vol. 67, no. 4, pp. 508-514, 2000.

[76] M. T. Harte, I. R. Haga, G. Maloney et al., "The poxvirus protein A52R targets toll-like receptor signaling complexes to suppress host defense," Journal of Experimental Medicine, vol. 197, no. 3, pp. 343-351, 2003.

[77] K. K. Ja, J. K. Hyun, M.-Y. Kim et al., "Expression of toll-like receptors in verruca and molluscum contagiosum," Journal of Korean Medical Science, vol. 23, no. 2, pp. 307-314, 2008.

[78] T. A. Syed, S. M. Hadi, Z. A. Qureshi, S. M. Ali, and M. S. Kwah, "Treatment of external genital warts in men with imiquimod $2 \%$ in cream. A placebo-controlled, double-blind study," Journal of Infection, vol. 41, no. 2, pp. 148-151, 2000.

[79] K. R. Beutner, S. L. Spruance, A. J. Hougham, T. L. Fox, M. L. Owens, and JR. Douglas J.M., "Treatment of genital warts with an immune-response modifier (imiquimod)," Journal of the American Academy of Dermatology, vol. 38, no. 2, pp. 230239, 1998. 
[80] B. Berman, "Imiquimod: a new immune response modifier for the treatment of external genital warts and other diseases in dermatology," International Journal of Dermatology, vol. 41, supplement 1, pp. 7-11, 2002.

[81] A. Sing, D. Rost, N. Tvardovskaia et al., "Yersinia Vantigen exploits toll-like receptor 2 and CD14 for interleukin 10-mediated immunosuppression," Journal of Experimental Medicine, vol. 196, no. 8, pp. 1017-1024, 2002.

[82] K. Ruckdeschel, O. Mannel, K. Richter et al., "Yersinia outer protein $\mathrm{P}$ of Yersinia enterocolitica simultaneously blocks the nuclear factor- $\kappa \mathrm{B}$ pathway and exploits lipopolysaccharide signaling to trigger apoptosis in macrophages," Journal of Immunology, vol. 166, no. 3, pp. 1823-1831, 2001.

[83] L. A. J. O’Neill, C. E. Bryant, and S. L. Doyle, “Therapeutic targeting of toll-like receptors for infectious and inflammatory diseases and cancer," Pharmacological Reviews, vol. 61, no. 2, pp. 177-197, 2009.

[84] L. Macedo, G. Pinhal-Enfield, V. Alshits, G. Elson, B. N. Cronstein, and S. J. Leibovich, "Wound healing is impaired in MyD88-deficient mice: a role for MyD88 in the regulation of wound healing by adenosine A2A receptors," American Journal of Pathology, vol. 171, no. 6, pp. 1774-1788, 2007.

[85] Y. Lai, A. Di Nardo, T. Nakatsuji et al., "Commensal bacteria regulate toll-like receptor 3-dependent inflammation after skin injury," Nature Medicine, vol. 15, no. 12, pp. 1377-1382, 2009.

[86] T. S. Kupper and R. C. Fuhlbrigge, "Immune surveillance in the skin: mechanisms and clinical consequences," Nature Reviews Immunology, vol. 4, no. 3, pp. 211-222, 2004.

[87] A. De Benedetto, R. Agnihothri, L. Y. McGirt, L. G. Bankova, and L. A. Beck, "Atopic dermatitis: a disease caused by innate immune defects?" The Journal of investigative dermatology, vol. 129, no. 1, pp. 14-30, 2009.

[88] S.-H. Cho, I. Strickland, M. Boguniewicz, and D. Y. M. Leung, "Fibronectin and fibrinogen contribute to the enhanced binding of Staphylococcus aureus to atopic skin," Journal of Allergy and Clinical Immunology, vol. 108, no. 2, pp. 269-274, 2001.

[89] S. Nishijima, S. Namura, S. Kawai, H. Hosokawa, and Y. Asada, "Staphylococcus aureus on hand surface and nasal carriage in patients ith atopic dermatitis," Journal of the American Academy of Dermatology, vol. 32, no. 4, pp. 677679, 1995.

[90] L. Y. McGirt and L. A. Beck, "Innate immune defects in atopic dermatitis," Journal of Allergy and Clinical Immunology, vol. 118, no. 1, pp. 202-208, 2006.

[91] P. Ahmad-Nejad, S. Mrabet-Dahbi, K. Breuer et al., "The Toll-like receptor $2 \mathrm{R} 753 \mathrm{Q}$ polymorphism defines a subgroup of patients with atopic dermatitis having severe phenotype," Journal of Allergy and Clinical Immunology, vol. 113, no. 3, pp. 565-567, 2004.

[92] M. Niebuhr, J. Langnickel, C. Draing, H. Renz, A. Kapp, and T. Werfel, "Dysregulation of toll-like receptor-2 (TLR2)-induced effects in monocytes from patients with atopic dermatitis: impact of the TLR-2 R753Q polymorphism," Allergy, vol. 63, no. 6, pp. 728-734, 2008.

[93] S. Weidinger, N. Novak, N. Klopp et al., "Lack of association between Toll-like receptor 2 and Toll-like receptor 4 polymorphisms and atopic eczema," Journal of Allergy and Clinical Immunology, vol. 118, no. 1, pp. 277-279, 2006.

[94] N. Novak, "New insights into the mechanism and management of allergic diseases: atopic dermatitis," Allergy, vol. 64, no. 2, pp. 265-275, 2009.
[95] S. Hoffjan, S. Stemmler, Q. Parwez et al., "Evaluation of the toll-like receptor 6 Ser249Pro polymorphism in patients with asthma, atopic dermatitis and chronic obstructive pulmonary disease," BMC Medical Genetics, vol. 6, article 34, 2005.

[96] D. Terhorst, B. N. Kalali, S. Weidinger et al., "Monocytederived dendritic cells from highly atopic individuals are not impaired in their pro-inflammatory response to toll-like receptor ligands," Clinical and Experimental Allergy, vol. 37, no. 3, pp. 381-390, 2007.

[97] G. B. Toews, P. R. Bergstresser, and J. W. Streilein, "Epidermal Langerhans cell density determines whether contact hypersensitivity or unresponsiveness follows skin painting with DNFB," Journal of Immunology, vol. 124, no. 1, pp. 445-453, 1980.

[98] W. Ptak, K. Bryniarski, M. Ptak et al., "Toll-like receptor ligands reverse suppression of contact hypersensitivity reactions induced by epicutaneous immunization with protein antigen," International Archives of Allergy and Immunology, vol. 139, no. 3, pp. 188-200, 2006.

[99] S. F. Martin, J. C. Dudda, E. Bachtanian et al., "Toll-like receptor and IL-12 signaling control susceptibility to contact hypersensitivity," Journal of Experimental Medicine, vol. 205, no. 9, pp. 2151-2162, 2008.

[100] P. Y. Ong, T. Ohtake, C. Brandt et al., "Endogenous antimicrobial peptides and skin infections in atopic dermatitis," The New England Journal of Medicine, vol. 347, no. 15, pp. 11511160, 2002.

[101] M. D. Howell, B. E. Kim, P. Gao et al., "Cytokine modulation of atopic dermatitis filaggrin skin expression," Journal of Allergy and Clinical Immunology, vol. 120, no. 1, pp. 150-155, 2007.

[102] C. A. Akdis, M. Akdis, T. Bieber et al., "Diagnosis and treatment of atopic dermatitis in children and adults: European Academy of Allergology and Clinical Immunology/American Academy of Allergy, Asthma and Immunology/PRACTALL Consensus Report," Journal of Allergy and Clinical Immunology, vol. 118, no. 1, pp. 152-169, 2006.

[103] T. Ruzicka, T. Bieber, E. Schöpf et al., "A short-term trial of tacrolimus ointment for atopic dermatitis," The New England Journal of Medicine, vol. 337, no. 12, pp. 816-821, 1997.

[104] A. S. Büchau, J. Schauber, T. Hultsch, A. Stuetz, and R. L. Gallo, "Pimecrolimus enhances TLR2/6-induced expression of antimicrobial peptides in keratinocytes," Journal of Investigative Dermatology, vol. 128, no. 11, pp. 2646-2654, 2008.

[105] L. A. Applegate, R. D. Ley, J. Alcalay, and M. L. Kripke, "Identification of the molecular target for the suppression of contact hypersensitivity by ultraviolet radiation," Journal of Experimental Medicine, vol. 170, no. 4, pp. 1117-1131, 1989.

[106] W. L. Morison, "Photoimmunology," Journal of Investigative Dermatology, vol. 77, no. 1, pp. 71-76, 1981.

[107] N. S. Scheinfeld, W. D. Tutrone, J. M. Weinberg, and V. A. Deleo, "Phototherapy of atopic dermatitis," Clinics in Dermatology, vol. 21, no. 3, pp. 241-248, 2003.

[108] M. Gilliet, C. Conrad, M. Geiges et al., "Psoriasis triggered by toll-like receptor 7 agonist imiquimod in the presence of dermal plasmacytoid dendritic cell precursors," Archives of Dermatology, vol. 140, no. 12, pp. 1490-1495, 2004.

[109] A. Farkas, G. Tonel, and F. O. Nestle, "Interferon- $\alpha$ and viral triggers promote functional maturation of human monocyte-derived dendritic cells," British Journal of Dermatology, vol. 158, no. 5, pp. 921-929, 2008. 
[110] L. S. Miller, O. E. Sørensen, P. T. Liu et al., "TGF- $\alpha$ regulates TLR expression and function on epidermal keratinocytes," Journal of Immunology, vol. 174, no. 10, pp. 6137-6143, 2005.

[111] N. R. Seung, E. J. Park, C. W. Kim et al., "Comparison of expression of heat-shock protein 60, Toll-like receptors 2 and 4 , and T-cell receptor $\gamma \delta$ in plaque and guttate psoriasis," Journal of Cutaneous Pathology, vol. 34, no. 12, pp. 903-911, 2007.

[112] A. A. Gaspari, "Innate and adaptive immunity and the pathophysiology of psoriasis," Journal of the American Academy of Dermatology, vol. 54, no. 3, pp. S67-S80, 2006.

[113] C. Wu, C. Li, L. Wei, and Z. Zheng, "Innate immune modulation of keratinocytes by antikeratin 16 antibodies," Experimental Dermatology, vol. 17, no. 8, pp. 645-652, 2008.

[114] M. A. Lowes, A. M. Bowcock, and J. G. Krueger, "Pathogenesis and therapy of psoriasis," Nature, vol. 445, no. 7130, pp. 866-873, 2007.

[115] B. J. Nickoloff, J.-Z. Qin, and F. O. Nestle, "Immunopathogenesis of psoriasis," Clinical Reviews in Allergy and Immunology, vol. 33, no. 1-2, pp. 45-56, 2007.

[116] B. S. Baker, A. F. Swain, L. Fry, and H. Valdimarsson, "Epidermal T lymphocytes and HLA-DR expression in psoriasis," British Journal of Dermatology, vol. 110, no. 5, pp. 555-564, 1984.

[117] L. M. Austin, M. Ozawa, T. Kikuchi, I. B. Walters, and J. G. Krueger, "The majority of epidermal T cells in psoriasis vulgaris lesions can produce type 1 cytokines, interferon$\gamma$, interleukin-2, and tumor necrosis factor- $\alpha$, defining TC1 (cytotoxic $\mathrm{T}$ lymphocyte) and $\mathrm{T}_{\mathrm{H}}^{1}$ effector populations: a type 1 differentiation bias is also measured in circulating blood T cells in psoriatic patients," Journal of Investigative Dermatology, vol. 113, no. 5, pp. 752-759, 1999.

[118] C. N. Ellis, D. C. Gorsulowsky, and T. A. Hamilton, "Cyclosporine improves psoriasis in a double-blind study," Journal of the American Medical Association, vol. 256, no. 22, pp. 3110-3116, 1986.

[119] J. Prinz, O. Braun-Falco, M. Meurer et al., "Chimaeric CD4 monoclonal antibody in treatment of generalised pustular psoriasis," The Lancet, vol. 338, no. 8762, pp. 320-321, 1991.

[120] J. R. Abrams, S. L. Kelley, E. Hayes et al., "Blockade of $\mathrm{T}$ lymphocyte costimulation with cytotoxic $\mathrm{T}$ lymphocyteassociated antigen 4-immunoglobulin (CTLA4Ig) reverses the cellular pathology of psoriatic plaques, including the activation of keratinocytes, dendritic cells, and endothelial cells," Journal of Experimental Medicine, vol. 192, no. 5, pp. 681-693, 2000.

[121] M. Sugiyama, P. M. Speight, S. S. Prime, and F. M. Watt, "Comparison of integrin expression and terminal differentiation capacity in cell lines derived from oral squamous cell carcinomas," Carcinogenesis, vol. 14, no. 10, pp. 2171-2176, 1993.

[122] S. L. Gottlieb, P. Gilleaudeau, R. Johnson et al., "Response of psoriasis to a lymphocyte-selective toxin (DAB389IL-2) suggests a primary immune, but not keratinocyte, pathogenic basis," Nature Medicine, vol. 1, no. 5, pp. 442-447, 1995.

[123] M. P. Schon, "Animal models of psoriasis—what can we learn from them?" Journal of Investigative Dermatology, vol. 112, no. 4, pp. 405-410, 1999.

[124] J. A. Snowden and D. C. Heaton, "Development of psoriasis after syngeneic bone marrow transplant from psoriatic donor: further evidence for adoptive autoimmunity," British Journal of Dermatology, vol. 137, no. 1, pp. 130-132, 1997.
[125] J. L. Curry, J.-Z. Qin, B. Bonish et al., "Innate immunerelated receptors in normal and psoriatic skin," Archives of Pathology and Laboratory Medicine, vol. 127, no. 2, pp. 178186, 2003.

[126] K. Kis, L. Bodai, H. Polyanka et al., "Budesonide, but not tacrolimus, affects the immune functions of normal human keratinocytes," International Immunopharmacology, vol. 6, no. 3, pp. 358-368, 2006.

[127] K. Rappersberger, M. Komar, M.-E. Ebelin et al., "Pimecrolimus identifies a common genomic anti-inflammatory profile, is clinically highly effective in psoriasis and is well tolerated," Journal of Investigative Dermatology, vol. 119, no. 4, pp. 876-887, 2002.

[128] N. H. R. Litjens, M. Rademaker, B. Ravensbergen et al., "Monomethylfumarate affects polarization of monocytederived dendritic cells resulting in down-regulated $\mathrm{T}_{\mathrm{H}}^{1}$ lymphocyte responses," European Journal of Immunology, vol. 34, no. 2, pp. 565-575, 2004.

[129] L. A. J. O'Neill, “Therapeutic targeting of Toll-like receptors for inflammatory and infectious diseases," Current Opinion in Pharmacology, vol. 3, no. 4, pp. 396-403, 2003.

[130] A. J. Thody and S. Shuster, "Control and function of sebaceous glands," Physiological Reviews, vol. 69, no. 2, pp. 383-416, 1989.

[131] C. C. Zouboulis, "Acne and sebaceous gland function," Clinics in Dermatology, vol. 22, no. 5, pp. 360-366, 2004.

[132] P. Georgel, K. Crozat, X. Lauth et al., "A toll-like receptor 2responsive lipid effector pathway protects mammals against skin infections with gram-positive bacteria," Infection and Immunity, vol. 73, no. 8, pp. 4512-4521, 2005.

[133] B. R. Vowels, S. Yang, and J. J. Leyden, "Induction of proinflammatory cytokines by a soluble factor of Propionibacterium acnes: implications for chronic inflammatory acne," Infection and Immunity, vol. 63, no. 8, pp. 3158-3165, 1995.

[134] D.-Y. Lee, K. Yamasaki, J. Rudsil et al., "Sebocytes express functional cathelicidin antimicrobial peptides and can act to kill Propionibacterium acnes," Journal of Investigative Dermatology, vol. 128, no. 7, pp. 1863-1866, 2008.

[135] M. Toyoda, M. Nakamura, and M. Morohashi, "Neuropeptides and sebaceous glands," European Journal of Dermatology, vol. 12, no. 5, pp. 422-427, 2002.

[136] R. Ganceviciene, S. Fimmel, E. Glass, and C. C. Zouboulis, "Psoriasin and follicular hyperkeratinization in acne comedones," Dermatology, vol. 213, no. 3, pp. 270-272, 2006.

[137] C. M. T. Chronnell, L. R. Ghali, R. S. Ali et al., "Human $\beta$ defensin- 1 and -2 expression in human pilosebaceous units: upregulation in acne vulgaris lesions," Journal of Investigative Dermatology, vol. 117, no. 5, pp. 1120-1125, 2001.

[138] I. Nagy, A. Pivarcsi, K. Kis et al., "Propionibacterium acnes and lipopolysaccharide induce the expression of antimicrobial peptides and proinflammatory cytokines/chemokines in human sebocytes," Microbes and Infection, vol. 8, no. 8, pp. 2195-2205, 2006.

[139] D. K. Chalker, J. L. Lesher Jr., and J. G. Smith Jr., "Efficacy of topical isotretinoin $0.05 \%$ gel in acne vulgaris: results of a multicenter, double-blind investigation," Journal of the American Academy of Dermatology, vol. 17, no. 2, pp. 251254, 1987.

[140] J. S. Weiss, "Current options for the topical treatment of acne vulgaris," Pediatric Dermatology, vol. 14, no. 6, pp. 480-488, 1997. 
[141] S. Gibbs, C. Backendorf, and M. Ponec, "Regulation of keratinocyte proliferation and differentiation by all-transretinoic acid, 9-cis-retinoic acid and 1,25-dihydroxy vitamin D3," Archives of Dermatological Research, vol. 288, no. 12, pp. 729-738, 1996.

[142] P. T. Liu, S. R. Krutzik, J. Kim, and R. L. Modlin, "Cutting edge: all-trans retinoic acid down-regulates TLR2 expression and function," Journal of Immunology, vol. 174, no. 5, pp. 2467-2470, 2005.

[143] P. A. Grange, C. Chéreau, J. Raingeaud et al., "Production of superoxide anions by keratinocytes initiates P. acnes-induced inflammation of the skin," PLoS Pathogens, vol. 5, no. 7, Article ID e1000527, pp. 1-14, 2009.

[144] P. A. Grange, J. Raingeaud, V. Calvez, and N. Dupin, "Nicotinamide inhibits Propionibacterium acnes-induced IL-8 production in keratinocytes through the NF- $\kappa \mathrm{B}$ and MAPK pathways," Journal of Dermatological Science, vol. 56, no. 2, pp. 106-112, 2009.

[145] L. Bianchi, A. Costanzo, E. Campione, S. Nisticò, and S. Chimenti, "Superficial and nodular basal cell carcinomas treated with an immune response modifier: a report of seven patients," Clinical and Experimental Dermatology, Supplement, vol. 28, no. 1, supplement, pp. 24-26, 2003.

[146] H. G. Kaporis, E. Guttman-Yassky, M. A. Lowes et al., "Human basal cell carcinoma is associated with Foxp3 $3^{+}$ $\mathrm{T}$ cells in a Th2 dominant microenvironment," Journal of Investigative Dermatology, vol. 127, no. 10, pp. 2391-2398, 2007.

[147] A. S. Weinberg, C. A. Ogle, and E. K. Shim, "Metastatic cutaneous squamous cell carcinoma: an update," Dermatologic Surgery, vol. 33, no. 8, pp. 885-899, 2007.

[148] A. I. Rubin, E. H. Chen, and D. Ratner, "Basal-cell carcinoma," The New England Journal of Medicine, vol. 353, no. 21, pp. 2262-2269, 2005.

[149] F. I. Ezughah, A. G. Affleck, A. Evans, S. H. Ibbotson, and C. J. Fleming, "Confirmation of histological clearance of superficial basal cell carcinoma with multiple serial sectioning and Mohs' micrographic surgery following treatment with imiquimod 5\% cream," Journal of Dermatological Treatment, vol. 19, no. 3, pp. 156-158, 2008.

[150] H.-J. Schulze, B. Cribier, L. Requena et al., "Imiquimod 5\% cream for the treatment of superficial basal cell carcinoma: results from a randomized vehicle-controlled phase III study in Europe," British Journal of Dermatology, vol. 152, no. 5, pp. 939-947, 2005.

[151] Y. Vun and G. Siller, "Use of 5\% imiquimod cream in the treatment of facial basal cell carcinoma: a 3-year retrospective follow-up study," Australasian Journal of Dermatology, vol. 47, no. 3, pp. 169-171, 2006.

[152] M. J. Bluth, L. C. Zaba, D. Moussai et al., "Myeloid dendritic cells from human cutaneous squamous cell carcinoma are poor stimulators of T-cell proliferation," Journal of Investigative Dermatology, vol. 129, no. 10, pp. 2451-2462, 2009.

[153] R. Marks, "Squamous cell carcinoma," The Lancet, vol. 347, no. 9003, pp. 735-738, 1996.

[154] J. Garcia-Zuazaga and S. M. Olbricht, "Cutaneous squamous cell carcinoma," Advances in Dermatology, vol. 24, pp. 33-57, 2008.

[155] H. Sadek, N. Azli, J. L. Wendling et al., "Treatment of advanced squamous cell carcinoma of the skin with cisplatin, 5-fluorouracil, and bleomycin," Cancer, vol. 66, no. 8, pp. 1692-1696, 1990.
[156] U. Wollina, G. Hansel, A. Koch, and E. Köstler, "Oral capecitabine plus subcutaneous interferon alpha in advanced squamous cell carcinoma of the skin," Journal of Cancer Research and Clinical Oncology, vol. 131, no. 5, pp. 300-304, 2005.

[157] J. C. Muhrer, "Melanoma: current incidence, diagnosis, and preventive strategies," Journal for Nurse Practitioners, vol. 5, no. 1, pp. 35-41, 2009.

[158] A. A. Smith, A. B. Cole, and S. W. Fosko, "Melanoma from the dermatologist's perspective," Facial Plastic Surgery Clinics of North America, vol. 11, no. 2, pp. 277-286, 2003.

[159] A. R. Doben and D. C. MacGillivray, "Current concepts in cutaneous melanoma: malignant melanoma," Surgical Clinics of North America, vol. 89, no. 3, pp. 713-725, 2009.

[160] A. S. Lonsdorf, H. Kuekrek, B. V. Stern, B. O. Boehm, P. V. Lehmann, and M. Tary-Lehmann, "Intratumor CpGoligodeoxynucleotide injection induces protective antitumor T cell immunity," Journal of Immunology, vol. 171, no. 8, pp. 3941-3946, 2003.

[161] D. E. Speiser, D. Liénard, N. Rufer et al., "Rapid and strong human CD8+ T cell responses to vaccination with peptide, IFA, and CpG oligodeoxynucleotide 7909," Journal of Clinical Investigation, vol. 115, no. 3, pp. 739-746, 2005.

[162] J. N. Kochenderfer, C. D. Chien, J. L. Simpson, and R. E. Gress, "Maximizing CD8+ T cell responses elicited by peptide vaccines containing CpG oligodeoxynucleotides," Clinical Immunology, vol. 124, no. 2, pp. 119-130, 2007.

[163] A. M. Krieg, "Development of TLR9 agonists for cancer therapy," Journal of Clinical Investigation, vol. 117, no. 5, pp. 1184-1194, 2007.

[164] M. Pashenkov, G. Goëss, C. Wagner et al., "Phase II trial of a toll-like receptor 9-activating oligonucleotide in patients with metastatic melanoma," Journal of Clinical Oncology, vol. 24, no. 36, pp. 5716-5724, 2006.

[165] A. Steinmann, J. O. Funk, G. Schuler, and P. Von den Driesch, "Topical imiquimod treatment of a cutaneous melanoma metastasis," Journal of the American Academy of Dermatology, vol. 43, no. 3, pp. 555-556, 2000.

[166] N. P. Peet, L. E. Baugh, S. Sunder, and J. E. Lewis, "Synthesis and antiallergic activity of some quinolinones and imidazoquinolinones," Journal of Medicinal Chemistry, vol. 28, no. 3, pp. 298-302, 1985.

[167] M. J. Reiter, T. L. Testerman, R. L. Miller, C. E. Weeks, and M. A. Tomai, "Cytokine induction in mice by the immunomodulator imiquimod," Journal of Leukocyte Biology, vol. 55, no. 2, pp. 234-240, 1994.

[168] M. P. Schön and M. Schön, "Imiquimod: mode of action," British Journal of Dermatology, vol. 157, no. 2, pp. 8-13, 2007.

[169] H. Hemmi, T. Kaisho, O. Takeuchi et al., "Small-antiviral compounds activate immune cells via the TLR7 MyD88dependent signaling pathway," Nature Immunology, vol. 3, no. 2, pp. 196-200, 2002.

[170] D. H. Dockrell and G. R. Kinghorn, "Imiquimod and resiquimod as novel immunomodulators," Journal of Antimicrobial Chemotherapy, vol. 48, no. 6, pp. 751-755, 2001.

[171] R. Skinner, "Role of topical therapies in the management of cutaneous disease," Journal of Cutaneous Medicine and Surgery, vol. 8, no. 3, supplement, pp. 22-31, 2004.

[172] J. E. McInturff, R. L. Modlin, and J. Kim, "The role of toll-like receptors in the pathogenesis and treatment of dermatological disease," Journal of Investigative Dermatology, vol. 125, no. 1, pp. 1-8, 2005. 
[173] M. Urosevic, R. Dummer, C. Conrad et al., "Diseaseindependent skin recruitment and activation of plasmacytoid predendritic cells following imiquimod treatment," Journal of the National Cancer Institute, vol. 97, no. 15, pp. 1143-1153, 2005.

[174] H. Y. Kang, T. J. Park, and S. H. Jin, "Imiquimod, a Toll-like receptor 7 agonist, inhibits melanogenesis and proliferation of human melanocytes," The Journal of Investigative Dermatology, vol. 129, no. 1, pp. 243-246, 2009.

[175] S. Adams, D. W. O’Neill, D. Nonaka et al., "Immunization of malignant melanoma patients with full-length NY-ESO-1 protein using TLR7 agonist imiquimod as vaccine adjuvant," Journal of Immunology, vol. 181, no. 1, pp. 776-784, 2008.

[176] S. Garantziotis, J. W. Hollingsworth, A. K. Zaas, and D. A. Schwartz, "The effect of toll-like receptors and tolllike receptor genetics in human disease," Annual Review of Medicine, vol. 59, pp. 343-359, 2008.

[177] F. Heil, P. Ahmad-Nejad, H. Hemmi et al., "The Toll-like receptor 7 (TLR7)-specific stimulus loxoribine uncovers a strong relationship within the TLR7, 8 and 9 subfamily," European Journal of Immunology, vol. 33, no. 11, pp. 29872997, 2003.

[178] S. S. Agarwala, J. M. Kirkwood, and J. Bryant, "Phase I, randomized, double-blind trial of 7-allyl-8-oxoguanosine (loxoribine) in advanced cancer," Cytokines, Cellular and Molecular Therapy, vol. 6, no. 4, pp. 171-176, 2000.

[179] E. Lotzova, C. A. Savary, A. Khan, and D. A. Stringfellow, "Stimulation of natural killer cells in two random-bred strains of athymic rats by interferon-inducing pyrimidinone," Journal of Immunology, vol. 132, no. 5, pp. 2566-2570, 1984.

[180] S. Euvrard, C. Ulrich, and N. Lefrancois, " Immunosuppressants and skin cancer in transplant patients: focus on rapamycin," Dermatologic Surgery, vol. 30, no. 4, pp. 628-633, 2004.

[181] N. J. Reynolds and W. I. Al-Daraji, "Calcineurin inhibitors and sirolimus: mechanisms of action and applications in dermatology," Clinical and Experimental Dermatology, vol. 27, no. 7, pp. 555-561, 2002.

[182] B. C. Wulff, D. F. Kusewitt, A. M. Vanbuskirk, J. M. ThomasAhner, F. J. Duncan, and T. M. Oberyszyn, "Sirolimus reduces the incidence and progression of UVB-induced skin cancer in SKH mice even with co-administration of cyclosporine A," Journal of Investigative Dermatology, vol. 128, no. 10, pp. 2467-2473, 2008.

[183] Z. Wang, J. Zhou, J. Fan et al., "Sirolimus inhibits the growth and metastatic progression of hepatocellular carcinoma," Journal of Cancer Research and Clinical Oncology, vol. 135, no. 5, pp. 715-722, 2009.

[184] R. P. Hickerson, D. Leake, L. N. Pho, S. A. Leachman, and R. L. Kaspar, "Rapamycin selectively inhibits expression of an inducible keratin (K6a) in human keratinocytes and improves symptoms in pachyonychia congenita patients," Journal of Dermatological Science, vol. 56, no. 2, pp. 82-88, 2009.

[185] T. Mathew, H. Kreis, and P. Friend, "Two-year incidence of malignancy in sirolimus-treated renal transplant recipients: results from five multicenter studies," Clinical Transplantation, vol. 18, no. 4, pp. 446-449, 2004.

[186] U. Nadiminti and J. L. Arbiser, "Rapamycin (sirolimus) as a steroid-sparing agent in dermatomyositis," Journal of the American Academy of Dermatology, vol. 52, no. 2, supplement 1, pp. S17-S19, 2005.
[187] A. F. Javier, Z. Bata-Csorgo, C. N. Ellis, S. Kang, J. J. Voorhees, and K. D. Cooper, "Rapamycin (Sirolimus) inhibits proliferating cell nuclear antigen expression and blocks cell cycle in the G1 phase in human keratinocyte stem cells," Journal of Clinical Investigation, vol. 99, no. 9, pp. 2094-2099, 1997.

[188] NIH, http://clinicaltrials.gov. 


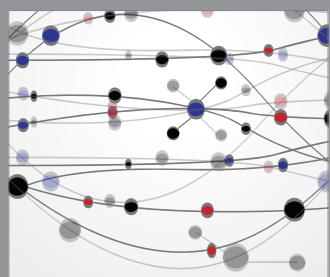

The Scientific World Journal
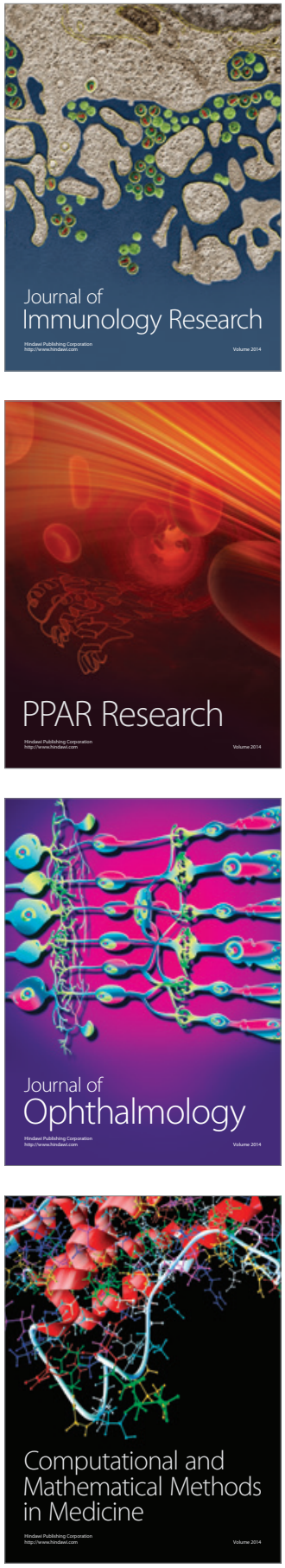

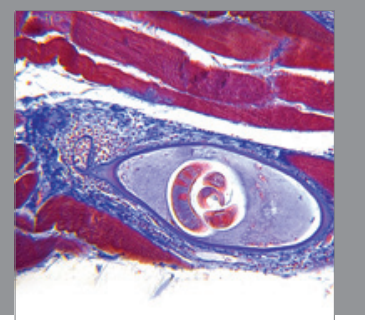

Gastroenterology

Research and Practice
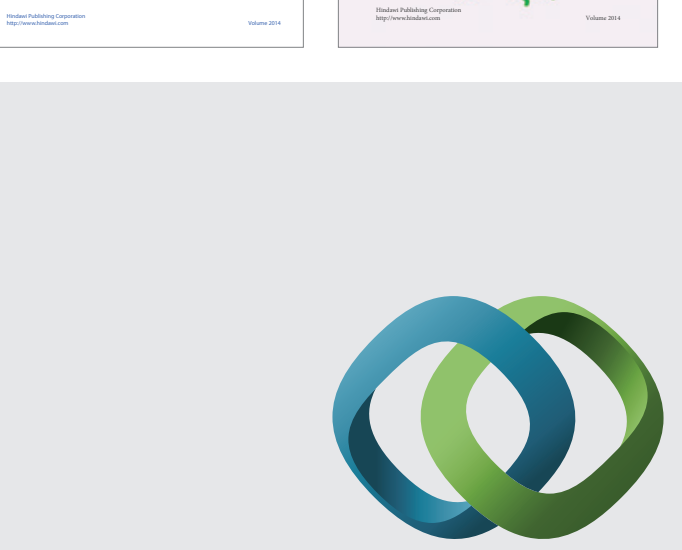

\section{Hindawi}

Submit your manuscripts at

http://www.hindawi.com
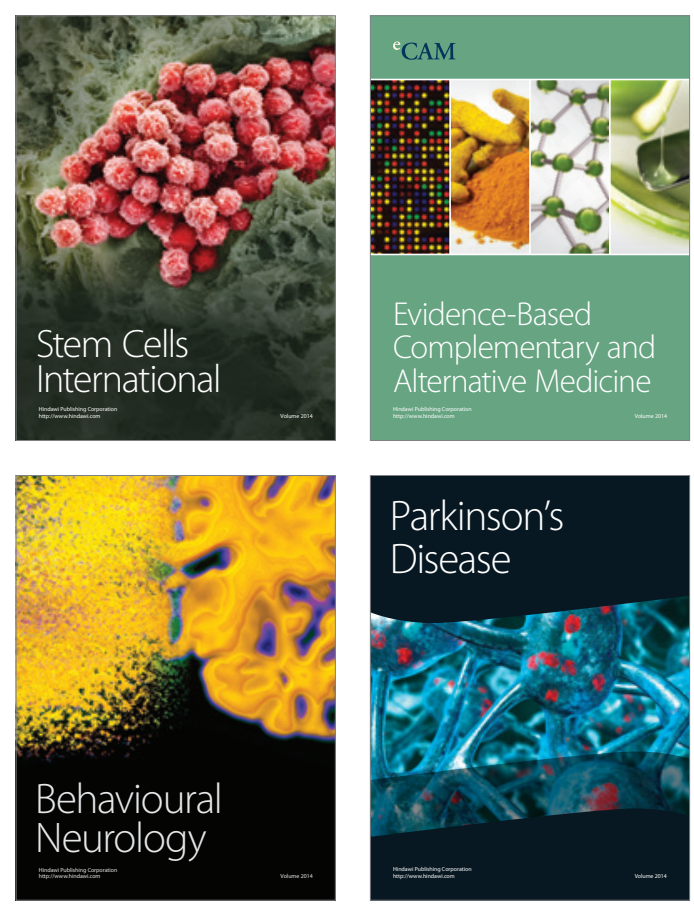

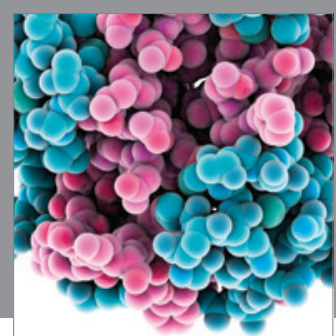

Journal of
Diabetes Research

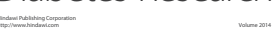

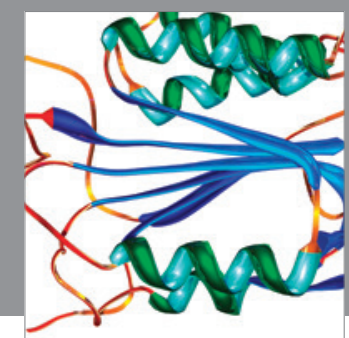

Disease Markers
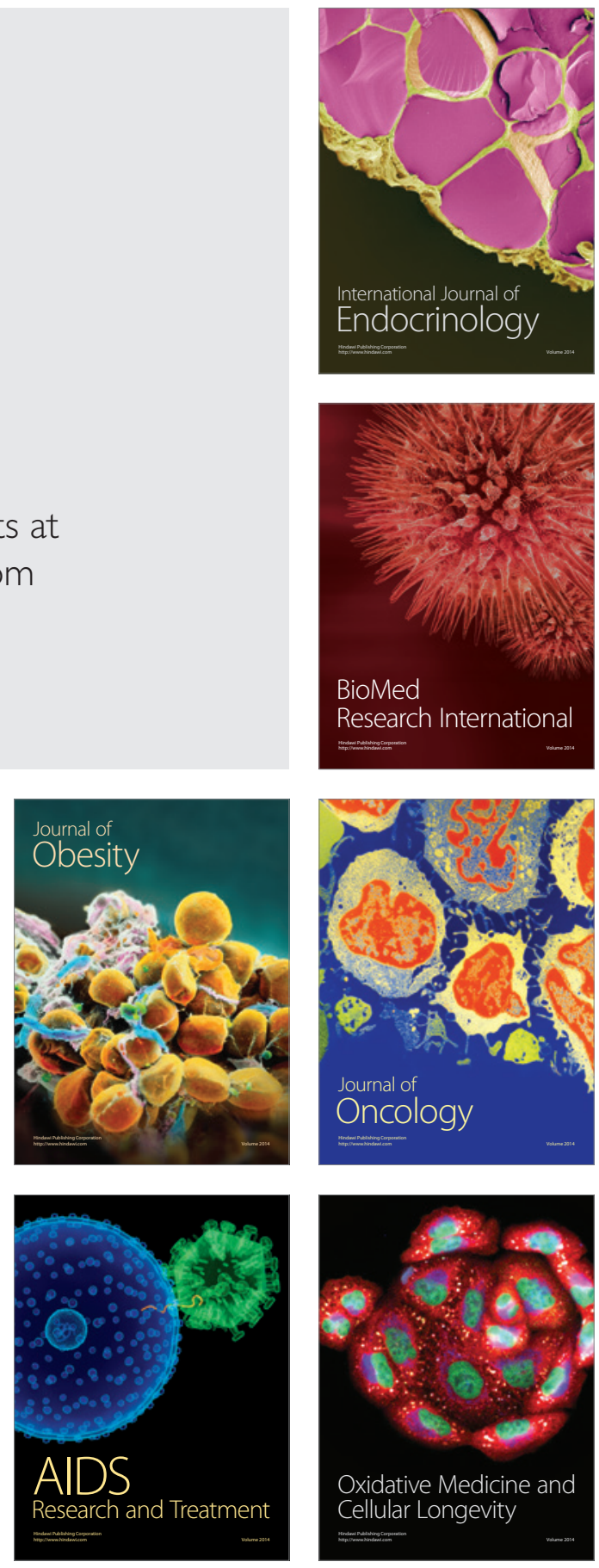